This PDF is a selection from a published volume from the National Bureau of Economic Research

Volume Title: Measuring Capital in the New Economy

Volume Author/Editor: Carol Corrado, John Haltiwanger and Dan Sichel, editors

Volume Publisher: University of Chicago Press

Volume ISBN: 0-226-11612-3

Volume URL: http://www.nber.org/books/corr05-1

Conference Date: April 26-27, 2002

Publication Date: August 2005

Title: The Valuation of Organization Capital

Author: Baruch Lev, Suresh Radhakrishnan

URL: http://www.nber.org/chapters/c10619

Chapter pages in book: $(73-110)$ 


\title{
The Valuation of \\ Organization Capital
}

\author{
Baruch Lev and Suresh Radhakrishnan
}

\subsection{Introduction}

It is widely observed that within industries or economic sectors some firms systematically outperform their competitors. Wal-Mart in retail, Dell in personal computers (PCs), IBM in computers and information technology services, Microsoft in software, UPS and Federal Express in shipping, Goldman Sachs in investment banking, Southwest among airlines, and similarly in practically every industry. Such super-normal performance, generally manifested by sustained growth in sales, earnings, and market value, is not attributed to monopoly power or competitionconstraining regulation, but rather to the organization of the leading enterprise. Such organization is manifested by unique systems and processes employed in the investment, production, and sales activities of the enterprise, along with the incentives and compensation systems governing its human resources. This collective resource, often dubbed "organization capital," is the major factor of production that is unique to the firm and thus capable of yielding abnormal - above cost of capital — returns, thereby generating enterprise growth. Most other factors of production, labor and capital in particular, are commodities in the modern economy, since com-

Baruch Lev is the Philip Bardes Professor of Accounting and Finance at Stern School of Business, New York University. Suresh Radhakrishnan is professor of accounting and information management at the School of Management, University of Texas at Dallas.

We are grateful to Rashad Abdel-Khalik, Jason Cummins, Rebecca Hendersson, James Myers, Konduru Sivaramkrishnan, Shivaram Rajagopal, Theodore Sougiannis, and participants of the 2001 Strategy Conference at Harvard University, the Texas Symposium at the University of Texas at Dallas, the Berkeley Conference at the University of California at Berkeley, the National Bureau of Economic Research 2002 Conference on Research in Income and Wealth, and seminars at University of Illinois, Urbana-Champaign, and Purdue University. 
petitors have equal access to them, and therefore yield, at best, the cost of capital. ${ }^{1}$ Organization capital, in contrast, is the persistent creator of value and growth for business enterprises.

It is easy to conjure examples of specific business processes and designs that make up organization capital, and even to conceptualize intuitively this resource as an extra, unmeasured factor of production responsible for abnormal firm performance. ${ }^{2}$ However, there exist no operational measures of organization capital. Such measures will be highly useful to a multitude of decision makers. Managers obviously need to track the size and growth of organization capital - the major source of competitive advantage - and benchmark it against the past (is our organization capital deteriorating?) and against rivals. Furthermore, valuing organization capital will enable managers to assess the return on investments in creating this resource, such as information technology (IT) and brand enhancement. Specifically, relating IT expenditures or brand enhancement outlays to changes in organizational capital will indicate the returns on these investments and guide overall resource allocation (invest less or more in IT?). Investors will similarly be eager to incorporate the value of organization capital in their corporate valuation models. In merger and acquisition cases, the value of organization capital should play a prominent role, since, as will be argued below, such capital is predominately tacit and difficult to transfer across firms, and hence of questionable value in acquisitions. Economic, organization, and management researchers in search of quantifying the elusive concept of "quality of management" will find an operational measure of organization capital highly instructive, since this capital essentially reflects the sum total of managerial decisions and activities.

In this study, we develop a firm-specific measure of organization capital and estimate it for a large sample of publicly traded companies. We test the validity of our measure within a widely used investment valuation model and show that it contributes significantly to the explanation of differences in market values of firms, beyond the traditional value indicators of assets in place and expected abnormal earnings (growth potential). We also document that financial analysts, the major information intermediaries in capital markets, fail to fully comprehend the value of firms' organization capital, probably because of the absence of relevant information on this re-

1. Even R\&D yields, on average, the cost of capital. Chan, Lakonishok, and Sougiannis (2001) report that the performance of firms conducting $R \& D$ is not superior, on average, to that of firms without R\&D. See also B. Hall (1993) for similar results.

2. Examples of specific business processes and designs that are components of organization capital are Wal-Mart's supply chain, where the reading of the barcodes of purchased products at the checkout register is directly transmitted to suppliers who are in turn largely responsible for inventory management; Cisco's Internet-based product installation and maintenance system, estimated by Cisco's chief financial officer to have saved $\$ 1.5$ billion over three years (Economist, June 26, 1999, p. 12); and Dell's pioneering built-to-order distribution system, where customers design their products. 
source in corporate financial reports (e.g., no data on IT expenditures, employee training, brand enhancement activities, etc.).

Section 3.2 of the paper discusses various concepts of organization capital and related research, while section 3.3 presents our methodology for measuring firm-specific organization capital and the empirical estimates. Section 3.4 examines the association between information technology - a key driver of organization capital — and our estimates of this resource; section 3.5 incorporates estimates of organization capital in a widely used valuation model to validate their usefulness, while section 3.6 concludes the paper.

\subsection{What Exactly Is Organization Capital?}

A succinct definition of organization capital was provided by Evenson and Westphal (1995, p. 2237): "organization capital . . . [is] the knowledge used to combine human skills and physical capital into systems for producing and delivering want-satisfying products." 3 Specifically, organization capital according to Evenson and Westphal relates to the following firm attributes (the specific examples are ours): (a) firms' operating capabilities, such as product design systems, production management and engineering (e.g., just-in-time inventory), input outsourcing (supply channels), and marketing technologies (e.g., on-line distribution channels); (b) investment capabilities, such as advanced project selection mechanisms (e.g., using real-options methodologies for project evaluation), personnel training, and financial engineering in fund raising and risk management (e.g., hedging assets, liabilities, and currency exposures with financial derivatives); and (c) innovation capabilities, such as unique research and development (R\&D) procedures (e.g., a scientific approach to drug development), adaptive capacity for learning from others, communities of practice to share information among employees, as well as decision and legal procedures for appropriating maximal benefits from intellectual property (e.g., patent licensing and technology turf protection). Organization capital is thus an agglomeration of technologies - business practices, processes and designs, and incentive and compensation systems - that together enable some firms to consistently and efficiently extract from a given level of physical and human resources a higher value of product than other firms find possible to attain. ${ }^{4}$

3. In a similar vein, Atkeson and Kehoe (2002, p. 1) wrote: "At least as far back as Marshall, economists have argued that organizations store and accumulate knowledge that affects their technology of production. This accumulated knowledge is a type of unmeasured capital that is distinct from the concepts of physical or human capital in the standard growth model."

4. Sometimes the absence of organization capital is mentioned as a potential source of future value: in an interview with Bill Miller (Barron's, February 3, 2003, p. 26), this most successful fund manager (an average annual return of 14.5 percent over the past 10 years) said the following about Home Depot: "People are talking about its problems . . . but all these problems are getting fixed. This is a company that didn't have any perpetual inventory, didn't 
Some researchers on organization capital view this resource as embodied in employees (e.g., Jovanovic 1979; Becker 1993). Elaborating on this view, Prescott and Visscher (1980, pp. 447-48) include the following factors in organization capital: (a) "what the firm knows about the abilities of its personnel . . improving matches between employees and jobs by measuring performance," (b) what "the firm learns about its employees to improve the match between employees working in teams," and (c) "the human capital of the firm's employees." Others view organization capital beyond that embedded in people, defining it as "a firm-specific capital good jointly produced with output and embodied in the organization itself" (Atkeson and Kehoe 2002, p. 3). Proponents of this approach include Arrow (1962), Rosen (1972), Tomer (1987), and Ericson and Pakes (1995). In the present study, we follow the latter-firm-embodied - concept of organization capital.

The competitive advantages conferred on firms by organization capital are mainly due to the fact that this resource cannot be completely codified and hence transferred to other organizations or imitated by them. As Evenson and Westphal (1995, p. 2213) note: "Much of the knowledge about how to perform elementary processes and about how to combine them in efficient systems is tacit, not physically embodied and neither codified nor readily transferable. Thus, though two producers in the same circumstances may use identical material inputs in conjunction with equal information, they may nonetheless employ what are really two distinct techniques owing to differences in understanding of the tacit elements." The car industry exemplifies the difficulties in imitating and adopting others' organization capital: with all that has been written about Japanese car manufacturers' efficiency systems (e.g., just-in-time production process) and the vast efforts to imitate these systems by competitors over the last two decades (including joint Japanese-U.S. production facilities, such as the GM-Toyota Nummi plant in Freemont, California), Japanese car manufacturers are still the world leaders in efficiency, profitability, and quality. ${ }^{5}$ Clearly, the essential elements of organization capital are not transferable across firms, even over extended time periods.

The partial tacitness of organization capital is among the major reasons this resource is hard to measure, at both the input and output levels. Part of the investment (input) in organization capital is not fully tracked by firms. For example, the cost of on-the-job training, particularly the mentoring of young employees by senior ones, is generally not recorded by the accounting system. Also not recorded as an investment are the extensive

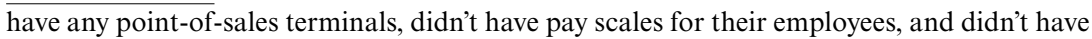
any centralized purchasing. It was remarkable what they didn't have, which tells you how powerful the economics of the business were."

5. In January 2004, Toyota Co. announced that in 2003 it had overtaken the Ford Motor Co. in worldwide car sales, and thus captured second place, behind General Motors, among car leaders. 
efforts of employees to better educate themselves and improve the efficiency of firms' production, research, and selling processes (the "suggestions box," for example). In general, the smaller the enterprise, the less likely that the accounting system will systematically track and record all the investment in organization capital. Consequently, firms and investors lack reliable input (cost) measures of organization capital. Nor is the output of organization capital easy to quantify. Such output-business designs and processes, for example - is essentially an intermediate product without a market price (see Aghion and Howitt, 1998, chap. 12, for discussion of difficulties in measuring knowledge output). Moreover, the accounting system does not segregate the contribution of organization capital to the firm's final output (sales, profits) from the contribution of other inputs, and therefore accounting is not equipped to value organizational capital.

Finally, to cap the measurement difficulties, the valuation of organization capital requires an estimate of its rate of obsolescence. The emergence of new systems and processes to replace those currently in use (e.g., Internetbased supply channels), along with imitation of elements of organization capital by competitors (J.C. Penney recently implemented a supply-chain system similar to Wal-Mart's) reduces the value of the firm's organization capital. Yet reliable estimates of the obsolescence rate of organization capital are not available. Thus, given the daunting challenges in measuring organization capital, it is not surprising that widely accepted measures of this important corporate resource are not available.

\subsection{Estimating Organization Capital}

\subsubsection{Methodology}

We model the firm's output, or sales (denoted by SALE), as a function of its major inputs: physical capital (PPE: property, plant, and equipment), labor (EMP: number of employees), and R\&D capital (RND), where RND represents the firm's innovative activities, that is, its intangible assets. The following function, which assumes constant returns to scale (as in R. Hall 2000), is used to estimate organization capital:

$$
\mathrm{SALE}_{i t}=a_{0 i t} \mathrm{PPE}_{i t}^{b_{1} t} \mathrm{EMP}_{i t}^{b_{2} t} \mathrm{RND}_{i t}^{b_{3 t} t} e_{i t} \text {, }
$$

where $\mathrm{SALE}_{i t}$ is the revenue of firm $i$ in year $t, a_{0 i t}$ stands for organization capital, $\mathrm{PPE}_{i t}$ is the net value of plant, property, and equipment, $\mathrm{EMP}_{i t}$ is the number of employees, $\mathrm{RND}_{i t}$ is the firm's $\mathrm{R} \& \mathrm{D}$ capital (the latter three variables are valued at year-end), and $e_{i t}$ is an error term. ${ }^{6}$

It is possible to estimate organization capital from the residual of

6. Note that the physical (PPE) and intangible (RND) inputs in (1) are measured in monetary values, whereas labor (EMP) is measured by the number of employees. This is due to the absence of a reliable, publicly reported monetary measure of firm-specific human capital. This is, in fact, an advantage, since the presence of the number of employees in expression (1) 
expression (1), either by extracting the systematic component of $e_{i t}$, or by inserting firm-specific dummy variables in equation (1). This approach was followed in the early attempts to estimate total factor productivity (TFP) in macroeconomic growth models (Solow 1957). ${ }^{7}$ The downside of estimating TFP, or our firm-specific organization capital, from the residual of a growth model is that a residual estimate is essentially a black box, reflecting random shock and various omitted variables along with organization capital, or TFP. This led Moses Abramovitz to his oft-mentioned characterization of residual-based TFP estimate as "a measure of our ignorance." Furthermore, it has been shown (Griliches and Mairesse 2000) that a residual estimation of TFP leads to downward-biased coefficient estimates. Accordingly, we have chosen to estimate the effect of organization capital on output by using the firm's reported sales, general, and administrative (SGA) expenses as a proxy for organization capital. ${ }^{8}$ This major income statement item includes most of the expenditures that generate organization capital, such as IT outlays, employee training costs, brand enhancement activities, payment to systems and strategy consultants, and the cost of setting up and maintaining Internet-based supply and distribution channels. For example, PepsiCo's SGA expenses of \$7.9, \$8.1, and \$8.5 billion in 2000, 2001, and 2002, respectively include advertising expenses, sales incentives, expenditures to support global and domestic affiliates, and expenditures on logistics of distribution systems (direct-store-delivery systems). Obviously, such brand enhancement and organization design outlays/investments are aimed at enhancing PepsiCo's organization capital. To be sure, not all of the firm's SGA expenses enhance organization capital-PepsiCo's SGA includes executives' compensation, for examplebut it is reasonable to assume that most of the expenditures aimed at creating and enhancing organization capital are included in the firm's SGA expenses.

Specifically, we model the organization capital variable in (1), $a_{0 i t}$, as follows:

$$
\log \left(a_{0 i t}\right)=b_{0 t}+b_{0 s t} \log \left(\mathrm{SGA}_{i t}\right),
$$

where SGA is the firm's sales, general, and administrative expenses in year $t$. We allow for two types of organization capital: (a) an economywide,

shifts the value of organization capital embedded in employees (particular skills and incentives) to the estimate of the firm's organization capital, $a_{0 i t}$, where it belongs.

7. In the basic growth model, the growth rate of GDP is related to capital, labor, and a residual, generally believed to reflect the economy's technology or innovation capabilities.

8. A recent McKinsey Global Institute (2002) study of the performance of 1000 companies during an eighteen-year period spanning 1982 to 1999 concludes that leaders tend to expand their SGA costs significantly above average during recessions as well as increasing their R\&D spending. That is, successful companies switch to an attack mode during bad times, because competition is weakened, and do this partially by expenditures reflected in the item SGA expenses. This is an example of building organization capital that helps companies perform better than average consistently. 
common organization capital $\left(b_{0 t}\right)$, which is available to all firms (e.g., a certain level of population education, the prevailing legal and institutional setting, etc.), and (b) a firm-specific organization capital $\left(b_{0 s t} \log \left[\mathrm{SGA}_{i t}\right]\right)$, which is developed and maintained by each firm (e.g., coded knowledge, production blueprints, business processes and procedures, marketing networks and channels, etc.).

A firm's SGA is determined by (a) the level of the firm's activity, as captured by its output (SALE), and (b) the committed portion of expenditures (e.g., multiyear employee training programs), captured by the lagged value of SGA. The level of output affects SGA because as the level of activity increases its business processes and practices need to be scaled up to accommodate the delivery of products and services for the larger base of customers. The committed portion of SGA reflects the adjustment costs involved in making changes in business processes and practices which are not instantaneous. To accommodate the endogeneity of SGA we model it as follows:

$$
\log \left(\mathrm{SGA}_{i t}\right)=\mathrm{g}_{0 t}+g_{1 t} \log \left(\mathrm{SALE}_{i t}\right)+g_{2 t} \log \left(\mathrm{SGA}_{i t-1}\right)+\log \left(u_{i t}\right) .
$$

We estimate expressions (1) and (3) by taking logarithms of annual changes, after substituting expression (2) into expression (1):

$$
\begin{aligned}
\log \left(\frac{\mathrm{SALE}_{i t}}{\mathrm{SALE}_{i, t-1}}\right)= & b_{0 t}+b_{0 s t} \log \left(\frac{\mathrm{SGA}_{i t}}{\mathrm{SGA}_{i, t-1}}\right)+b_{1 t} \log \left(\frac{\mathrm{PPE}_{i t}}{\mathrm{PPE}_{i, t-1}}\right) \\
& +b_{2 t} \log \left(\frac{\mathrm{EMP}_{i t}}{\mathrm{EMP}_{i, t-1}}\right)+b_{3 t} \log \left(\frac{\mathrm{RND}_{i t}}{\mathrm{RND}_{i, t-1}}\right) \\
& +\log \left(\frac{e_{i t}}{e_{i, t-1}}\right)
\end{aligned}
$$

$$
\begin{aligned}
\log \left(\frac{\mathrm{SGA}_{i t}}{\mathrm{SGA}_{i, t-1}}\right)= & g_{0 t}+b_{1 t} \log \left(\frac{\mathrm{SALE}_{i t}}{\mathrm{SALE}_{i, t-1}}\right)+b_{1 t} \log \left(\frac{\mathrm{SGA}_{i t-1}}{\mathrm{SGA}_{i, t-2}}\right) \\
& +\log \left(\frac{u_{i t}}{u_{i, t-1}}\right) .
\end{aligned}
$$

We estimate expressions (4) and (5) using the two-stage least squares procedure cross-sectionally for each sample year (1978-2002) for all firms listed on the Compustat database that operate in twelve major industry categories and that have the required financial data (see appendix for the industry classification). ${ }^{9}$

Our sample consists of all firms with both annual sales and total assets

9. We use the Fama and French $(1988,1997)$ industry classification, which is widely applied in finance research, since in the next section we use capital market values to validate our organization capital estimates. 
greater than $\$ 5$ million, to avoid insignificant enterprises. Data for each sample firm on sales (Compustat data item no. 12); plant, property, and equipment (PPE; no. 8); number of employees (no. 29); annual R\&D expense (no. 46); and SGA expense (no. 132) are obtained from the Compustat Annual Database. We estimate research and development capital (RND) by capitalizing and amortizing the annual research and development expenditures (R\&D) over five years (a 20\% annual amortization rate), ${ }^{10}$ and we set the R\&D expense to zero when data were not available on Compustat. We generate our estimates for each sample year for two groups of firms - those with R\&D expenditures and those without R\&D expenditures - to investigate differences in organization capital between firms that formally invest in R\&D and those that do not. The sample contains 57,258 non-R\&D and 32,979 R\&D firm-year observations, spanning the period 1978-2002.

Panel A of table 3.1 provides descriptive statistics of the variables in expressions (4) and (5), whereas panel B presents the means and respective $t$-values of the 300 estimates (twenty-five years spanning 1978-2002 and twelve industry groups each year) of expression (4) for the R\&D and non$\mathrm{R} \& \mathrm{D}$ firms. It is evident from panel A that, at the mean, $R \& D$ firms are larger than non-R\&D ones, although at the median the reverse is true. This indicates the presence in the sample of some very large R\&D firms (e.g., General Electric, Microsoft, Pfizer). ${ }^{11}$ Panel B indicates that, for both $\mathrm{R} \& \mathrm{D}$ and non-R\&D firms, the logarithm of growth in the common, economywide organization capital (i.e., the intercept) is 0.03 , which represents approximately 3 percent of average output growth. This is consistent with the aggregate Divisia index estimates in R. Hall (2000). For the R\&D (non$\mathrm{R} \& \mathrm{D})$ firms, the marginal productivity of plant, property, and equipment $\left(b_{1}^{*}\right.$ in expression [3]) is $0.08(0.10)$, the marginal productivity of human capital $\left(b_{2}^{*}\right)$ is $0.33(0.15)$, and the marginal productivity of research and development $\left(b_{3}^{*}\right)$ is 0.09 (where the asterisk indicates the mean coefficient estimate across all years and industries). The difference between the marginal productivities of PPE for the subsamples of R\&D and non-R\&D firms is not significant at the $P<0.01$ percent level, suggesting that R\&D does not appreciably affect the marginal productivity of physical assets. In contrast, the difference between the marginal productivities of employees (EMP) across the R\&D and non-R\&D subsamples is statistically significant at the $P<0.01$ level, suggesting that R\&D enhances the effi-

10. Most empirical estimates of the amortization rate of $R \& D$ yield an annual rate of $15-$ 20 percent (e.g., Lev and Sougiannis 1996).

11. In table 3.1, panel A, for firms with R\&D: the maximum (minimum) SALE is that of General Motors (Human Genome Sciences), PPE is that of Nippon, Telephone and Telegraph (Abiomed Inc.), EMP is that of General Motors (Franklin Telekom), SGA is that of IBM (Vacu Dry), and RND is that of General Motors (Vacu Dry); and for firms without R\&D: the maximum (minimum) SALE is that of Wal-Mart (Lovelady Ike), PPE is that of Deutche Telekom (Washington Homes), EMP is that of Wal-Mart (Lovelady Ike), SGA is that of Wal-Mart (Turf Paradise). 


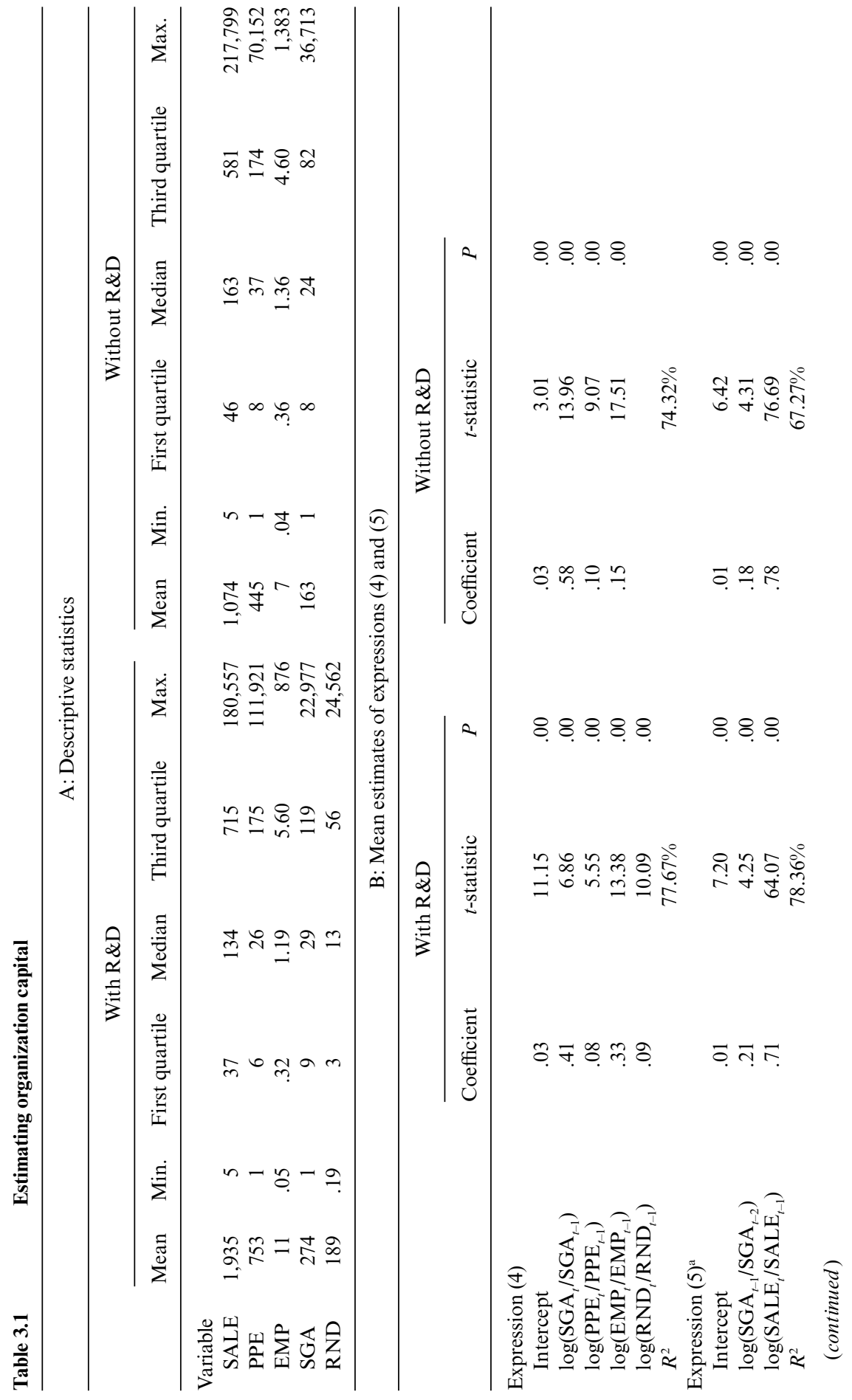




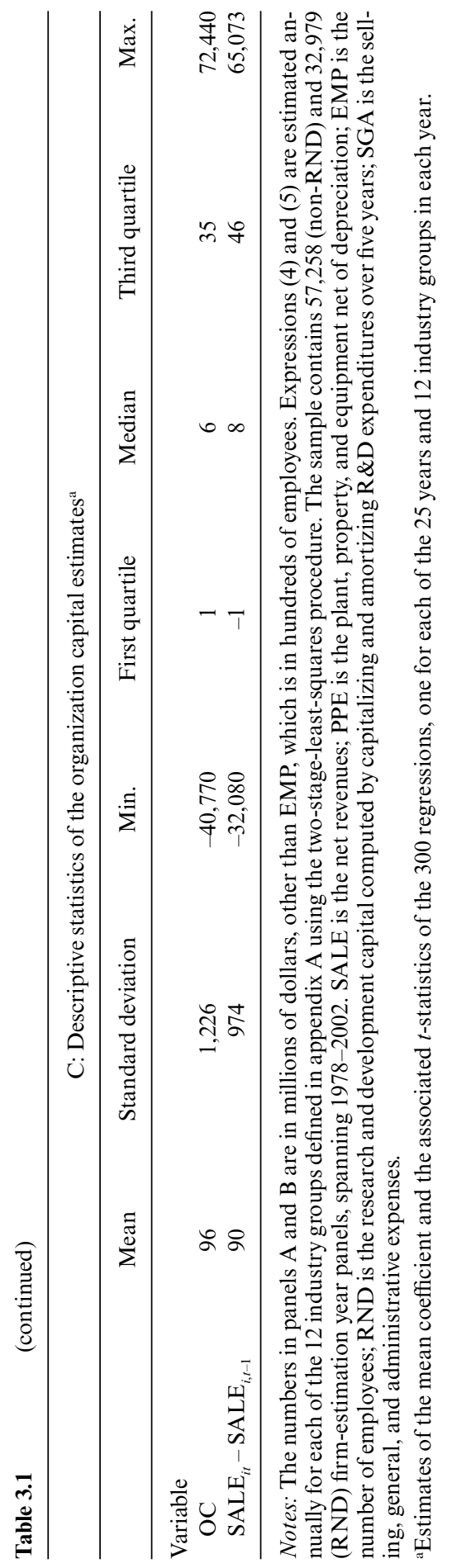


ciency of employees, apparently through process $\mathrm{R} \& \mathrm{D}$. The marginal productivity of SGA $\left(b_{0 s}^{*}\right)$, our proxy for organization capital, is 0.41 and 0.58 for $R \& D$ and non-R\&D firms, respectively, where the difference in the marginal productivities is significant at the $P<0.01$ level. This suggests that non-R\&D firms sustain their competitive edge through organizational processes and designs, generated by SGA expenditures, to compensate for the absence of R\&D.

\subsubsection{Deriving Firm-Specific Estimates}

We now derive firm-specific estimates of the annual contribution of organization capital to output growth by transforming the coefficient estimates of expression (4) into monetary values. Specifically, we define two expectations of firm's output (sales) from expression (4): the expected output of firm $i$ in year $t$ with and without the common and firm-specific organization capital, estimated by the proxy SGA. ${ }^{12}$ From expression (4), the expected output of firm $i$ in year $t$ with organization capital is as follows:

$$
\text { (6) } \begin{aligned}
\mathrm{SALE}_{i t}^{*} & =\mathrm{SALE}_{i, t-1} \exp \left[b_{0 t}^{*}+b_{0 s t}^{*} \log \left(\frac{\mathrm{SGA}_{i t}}{\mathrm{SGA}_{i, t-1}}\right)+b_{1 t}^{*} \log \left(\frac{\mathrm{PPE}_{i t}}{\mathrm{PPI}_{i, t-1}}\right)\right. \\
& \left.+b_{2 t}^{*} \log \left(\frac{\mathrm{EMP}_{i t}}{\mathrm{EMP}_{i, t-1}}\right)+b_{3 t}^{*} \log \left(\frac{\mathrm{RND}_{i t}}{\mathrm{RND}_{i, t-1}}\right)\right],
\end{aligned}
$$

where $b_{n t}^{*}$ for $n=0,0 S$ ( $S$ for specific organization capital) and 1,2, 3 are the coefficient estimates obtained from the annual cross-sectional estimation of expression (3) for each industry described above.

The expected output of firm $i$ in year $t$ without the effect of organization capital is as follows:

$$
\text { (7) } \begin{aligned}
\mathrm{SALE}_{i t}^{* *}= & \mathrm{SALE}_{i, t-1} \exp \left[b_{1 t}^{*} \log \left(\frac{\mathrm{PPI}_{i t}}{\mathrm{PPI}_{i, t-1}}\right)+b_{2 t}^{*} \log \left(\frac{\mathrm{EMP}_{i t}}{\mathrm{EMP}_{i, t-1}}\right)\right. \\
& \left.+b_{3 t}^{*} \log \left(\frac{\mathrm{RND}_{i t}}{\mathrm{RND}_{i, t-1}}\right)\right] .
\end{aligned}
$$

Given the two output expectations, expressions (6) and (7), our firmspecific measure of organization capital (OC) is the difference between expected sales with and without organization capital:

$$
\mathrm{OC}_{i t}=\mathrm{SALE}_{i t}^{*}-\mathrm{SALE}_{i, t-1}^{* *},
$$

where SALE* and SALE it $_{i t}^{* *}$ are defined by equations (6) and (7), respectively. ${ }^{13}$ Note that the annual estimate of OC in equation (8) is not the total

12. We used the expected SGA using our estimates of expression (5) and obtained qualitatively similar results.

13. It is possible to estimate organization capital (OC) by subtracting expected sales without OC, expression (5), from the firm's actual sales $\left(\mathrm{SALE}_{i t}\right)$, rather than from expected sales with OC (expression [4]). The drawback of such an estimate is that the consequent OC mea- 
value of the firm's organization capital but is rather the annual contribution of organization capital to output growth.

Table 3.1, panel D (top row), provides descriptive statistics for the organization capital (OC) estimate. The mean OC is $\$ 96$ million, representing about 4 percent of average sales (SALE in table 3.1, panel A). The estimate of 4 percent average contribution of organization capital to output is very close to Atkeson and Kehoe's (2002, table 1) estimate of the share of the economy's organization capital in aggregate output, which ranges between 2.7 percent and 4.0 percent. Note also that somewhat less than 25 percent of the sample firms have negative OC values, indicating that organization capital can be counterproductive in certain years. Finally, since the mean annual change in sales is $\$ 90$ million for our sample (table 3.1, panel D), the estimated average contribution of organization capital to sales growth-\$96 million - is almost 100 percent, indicating the importance of organization capital in generating output growth. ${ }^{14}$

\subsubsection{Firm-Specific Examples}

To provide intuition and insight into our organization capital measure, table 3.2 presents the underlying data and final estimates for IBM, covering the period 1994-2000. Panel A reports the values of the variables in expression (3): sales (SALE, the dependent variable), as well as the independent variables - SGA; PPE; number of employees (EMP in thousands); and R\&D capital (RND). ${ }^{15}$ Panel B reports the annual growth rates (log of successive yearly values) of the variables in panel A. Panel C provides the annual cross-sectional estimates of the coefficients of expression (3), run for the firms in the industry in which IBM operates. ${ }^{16}$ Note the relative stability of the firm-specific organization capital coefficient, $b_{0 s t}$. Panel D derives the estimates of IBM's annual contributions of organization capital (details in notes to table 3.2): columns (B) and (D) provide for each year the $\log$ of predicted sales growth, with and without organization capital, respectively; that is, using expressions (6) and (7) with the coefficients reported in panel $\mathrm{C}$, multiplied by the respective logs of the growth variables in panel B. Columns (C) and (E) of panel D provide the antilogs of columns

sure includes the noise in the regression residual, whereas our estimate in expression (6) eliminates the residual.

14. In table 3.1, panel C, the maximum (minimum) organization capital estimate is that of Total Fina in 2000 (Honda Motors Ltd. in 2002), and the change in sale is that of Total Fina in 2000 (Mitsui and Co. in 1995).

15. The period covered (1994-2000) marks the remarkable recovery of IBM under then chief executive officer (CEO) Lou Gerstner, who took the helm in late 1993 of the thenstruggling company. Data in panel A tell part of the recovery story: a continuous increase in sales (from $\$ 62.7$ billion to $\$ 87.5$ billion) while cutting expenses (except for payroll and capital expenditures).

16. These computer industry estimates (SIC 7370) can be compared with the overall sample (and time) estimates of expression (4) in panel B of table 3.1. 


\begin{tabular}{cccccc}
\hline \multicolumn{5}{c}{ A: Fundamental data } \\
\hline Year & SALE & SGA & PPE & EMP & RND \\
\hline 1994 & 62,716 & 23,840 & 17,521 & 256 & 14,504 \\
1995 & 64,052 & 20,279 & 16,664 & 220 & 12,960 \\
1996 & 71,940 & 20,448 & 16,579 & 225 & 13,625 \\
1997 & 75,947 & 21,508 & 17,407 & 241 & 12,934 \\
1998 & 78,508 & 21,511 & 18,347 & 269 & 12,829 \\
1999 & 81,667 & 21,708 & 19,631 & 291 & 13,039 \\
2000 & 87,548 & 21,854 & 17,590 & 307 & 13,351 \\
\hline
\end{tabular}

B: $\log ($ growth $)$

\begin{tabular}{ccccc}
\hline Year & $\log \left(\mathrm{SGA}_{t} / \mathrm{SGA}_{t-1}\right)$ & $\log \left(\mathrm{PPE}_{t} / \mathrm{PPE}_{t-1}\right)$ & $\log \left(\mathrm{EMP}_{t} / \mathrm{EMP}_{t-1}\right)$ & $\log \left(\mathrm{RND}_{t} / \mathrm{RND}_{t-1}\right)$ \\
\hline 1995 & -.1618 & -.0501 & -.1531 & -.1126 \\
1996 & .0083 & -.0051 & .0247 & .0500 \\
1997 & .0505 & .0487 & .0656 & -.0520 \\
1998 & .0001 & .0526 & .1132 & -.0081 \\
1999 & .0091 & .0676 & .0771 & .0162 \\
2000 & .0067 & -.1098 & .0546 & .0236 \\
\hline
\end{tabular}

C: Estimates of expression (4)

\begin{tabular}{lccccl}
\hline Year & $b_{0 t}$ & $b_{0 s t}$ & $b_{1 t}$ & $b_{2 t}$ & $b_{3 t}$ \\
\hline 1995 & .07 & .30 & .10 & .39 & .08 \\
1996 & .01 & .31 & .10 & .34 & .08 \\
1997 & -.01 & .24 & .09 & .36 & .07 \\
1998 & -.02 & .25 & .10 & .33 & .08 \\
1999 & .01 & .31 & .12 & .34 & .09 \\
2000 & .02 & .27 & .09 & .32 & .11 \\
\hline
\end{tabular}

D: Computations

\begin{tabular}{|c|c|c|c|c|c|c|}
\hline Year & $\begin{array}{l}\text { SALE }_{t-1} \\
\text { (A) }\end{array}$ & $\begin{array}{l}\log \text { (predicted } \\
\text { sales growth } \\
\text { with OC) } \\
\text { (B) }\end{array}$ & $\begin{array}{l}\text { Predicted } \\
\text { sales } \\
\text { with OC } \\
\text { (C) }\end{array}$ & $\begin{array}{l}\log \text { (predicted } \\
\text { sales growth } \\
\text { without OC) } \\
\text { (D) }\end{array}$ & $\begin{array}{c}\text { Predicted } \\
\text { sales } \\
\text { without OC } \\
\text { (E) }\end{array}$ & $\begin{array}{c}\text { Organization } \\
\quad \text { capital } \\
(F)=(C)-(E)\end{array}$ \\
\hline 1995 & 62,716 & -.0486 & 59,741 & -.0628 & 58,899 & 842 \\
\hline 1996 & 64,052 & .0247 & 65,655 & .0061 & 64,447 & 1,208 \\
\hline 1997 & 71,940 & .0259 & 73,831 & .0129 & 72,872 & 959 \\
\hline 1998 & 75,947 & .0181 & 77,333 & .0046 & 76,301 & 1,032 \\
\hline 1999 & 78,508 & .0479 & 82,361 & .0122 & 79,476 & 2,885 \\
\hline 2000 & 81,667 & .0293 & 84,093 & -.0055 & 81,221 & 2,872 \\
\hline
\end{tabular}

Notes: The numbers in panel A are in millions of dollars, other than EMP, which is in thousands of employees. The numbers in panel B are the logarithm of growth of the respective variables (e.g., $-.0501=$ $\log (16,664 / 17,521)$. Expressions (4) and (5) are estimated annually for each of the 12 industry groups defined in appendix A using the two-stage-least-squares procedure. Panel D, column (B) $=b_{0 t}+b_{0 s t}$ $\log \left(\mathrm{SGA}_{i t} / \mathrm{SGA}_{i, t-1}\right)+b_{1 t} \log \left(\mathrm{PPE}_{i t} / \mathrm{PPE}_{i, t-1}\right)+b_{2 t} \log \left(\mathrm{EMP}_{i t} / \mathrm{EMP}_{i, t-1}\right)+b_{3 t} \log \left(\mathrm{RND}_{i t} / \mathrm{RND}_{i, t-1}\right)$, where estimates of $b_{i t}$ are given in panel C. Panel D, column $(\mathrm{C})=\exp \{$ column (B) $\} \mathrm{SALE}_{t-1}$. Panel D, column $(\mathrm{D})=b_{1 t} \log \left(\mathrm{PPE}_{i t} / \mathrm{PPE}_{i, t-1}\right)+b_{2 t} \log \left(\mathrm{EMP}_{i t} / \mathrm{EMP}_{i, t-1}\right)+b_{3 t} \log \left(\mathrm{RND}_{i t} / \mathrm{RND}_{i, t-1}\right)$, where estimates of $b_{j t}$ are given in panel C. Panel D, column (E) $=\exp \{$ column (D) $\} \mathrm{SALE}_{t-1}$. Panel D, column $(\mathrm{F})=$ column (D) - column (E). See table 3.1 notes for variable definitions. 


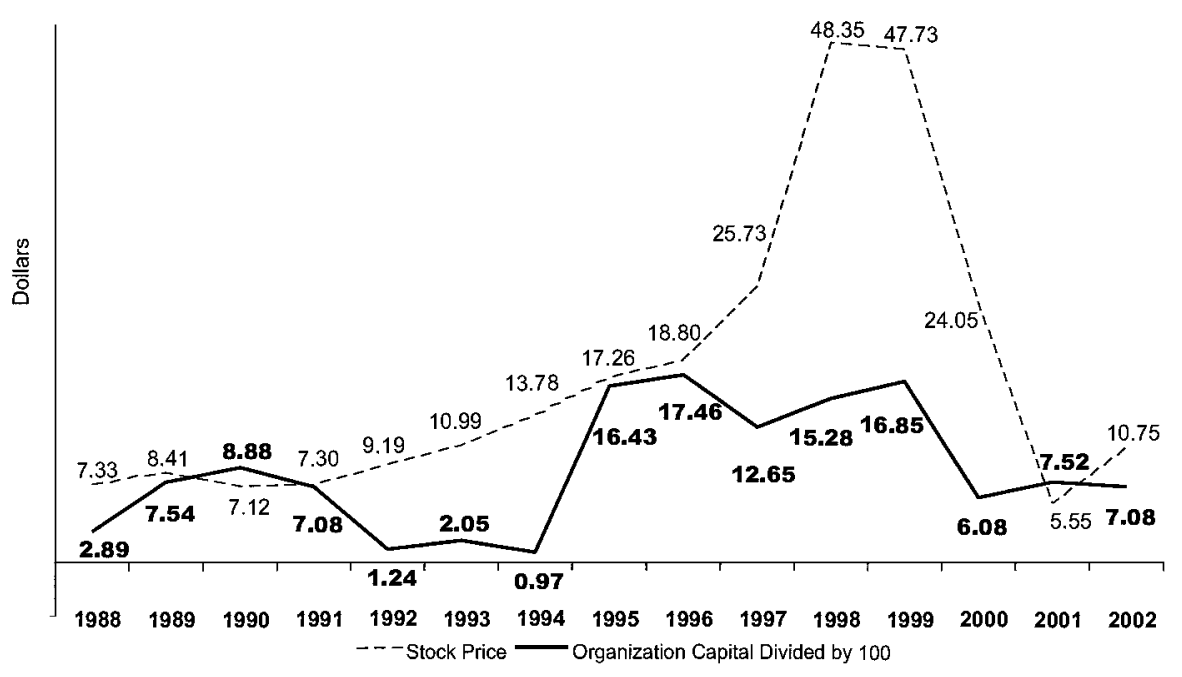

Fig. 3.1 Example of Xerox

(B) and (D), namely the conversion to monetary values of IBM's predicted sales (with and without organization capital). Finally, the annual contribution of organization capital to IBM's output is reported in the rightmost column of panel D, as the difference between columns (C) and (E). The organization capital data show a strong and sustained improvement in IBM's organization capital during 1995-2000, corroborating the highly successful turnaround of IBM. Interestingly, of the overall sales growth of IBM over that period, amounting to $\$ 19$ billion (81.7-62.7), organization capital contributed $\$ 10$ billion (the sum of the annual contributions of organization capital), or 50 percent.

Since the contribution of organization capital is reflected in the firm's performance (e.g., sales and earnings growth), the question arises whether the measurement of organization capital adds useful information beyond that in sales or other financial data. This question is addressed comprehensively in the next section, but the following case of Xerox Corp., which fell on hard times in the late 1990s, provides a first inkling. Figure 3.1 presents certain financial and organization capital data for Xerox. The line and numbers in bold are based on our measure of organization capital (the number is the organization capital divided by 100). The dotted line and associated numbers represent the stock price adjusted for stock splits. The firm's sales (not shown in figure 3.1) increased continuously through 2000, as did net income (the latter interrupted by a few years of losses, mainly due to corporate acquisition costs and other accounting writeoffs). As shown in figure 3.1, Xerox stock followed suit with an almost sevenfold increase 
in price over the 1988-2000 period. Alas, the stock price collapsed in 20012 , primarily as a reaction to reported losses and accounting scandals. It is clear that investors were totally surprised by Xerox's collapse.

Xerox's organization capital, however, exhibits a different pattern. The annual contributions of organization capital to output $\left(\mathrm{OC}_{t}\right)$ spanned $\$ 700$ 1,200 million throughout 1988-97 (with the exception of 1991-94, when OC contributions were close to $\$ 100$ million). From 1998, however-two years before the downturn in sales and the stock price-Xerox annual organization capital contributions decreased sharply to about $\$ 700$ million in the following three years. Thus, our organization capital measure provided a two-year advance warning of Xerox travails, relative to its financial reports and stock market investors and analysts. Thus, as demonstrated by the Xerox case and confirmed over the entire sample in section 3.5, the information conveyed by the organization capital measure is not subsumed by the contemporaneous sales and earnings data of the companies; rather, it provides a more timely indication about the firm's economic conditions and performance.

\subsection{Organization Capital and Information Technology}

Information technology (IT) is a major enabler of organization capital. Effective business processes and practices, such as Internet-based supply and distribution channels, production design and control systems, or riskhedging mechanisms, rely heavily on the IT infrastructure. Indeed, Brynjolfsson and Yang (1999) explain their unexpectedly large estimate of the contribution of IT to firm value - about $\$ 10$ of value for $\$ 1$ of IT investment-by postulating that IT expenditures proxy in their regressions for the unmeasured organization capital, which is the intrinsic contributor of firm value. Accordingly, if our measure captures organization capital, it should be correlated with IT expenditures. ${ }^{17}$

Public companies, however, do not identify their expenditures on IT in financial reports. Therefore, for a subsample of firms, we obtained annual data on firm-specific IT expenditures from Information Week reports published in its IT 500 survey. ${ }^{18}$ To quantify the association between OC and IT expenditures, we estimate the following regression:

$$
\left.\log \left(\mathrm{OC}_{i t}\right)=a_{0}+a_{1} \text { [Year dummies }\right]+a_{2} \mathrm{MKS}_{i t}+a_{3} \log \left(\mathrm{IT}_{i, t-1}\right)+e_{i t},
$$

17. Early in the ongoing debate about IT's contribution to productivity and growth, Robert Solow commented: "I see IT everywhere, except in the productivity data" (Gordon 2000). Subsequent studies (e.g., Gordon and Baily 1993) recorded substantial IT contribution, but only in a few industries, particularly computers and software. Others (e.g., Brynjolfsson and Hitt 1996) reported a substantial, widespread contribution.

18. These surveys were published during 1991-97. Information Week ceased to publish the IT expenditure data from 1998 onward. 
where $\mathrm{OC}_{i t}$ is firm $i$ 's organization capital contribution in year $t$ (1991-97), $\mathrm{IT}_{i t}$ is firm $i$ 's information technology expenditures in year $t$, and $\mathrm{MKS}_{i t}$ is firm $i$ 's market share in year $t$, measured as the percentage of firm $i$ 's sales relative to the total sales of all the firms in its industry group (see appendix). We incorporate the market share indicator in expression (9) as a control variable. Firms with effective organization capital will capture significant market share. Thus, the presence of the firm's market share in equation (9) controls for certain missing variables that affect organization capital, thereby allowing us to focus on the unique contribution of IT to OC. We use the information technology expenditures in the preceding year $\left(\mathrm{IT}_{i, t-1}\right)$ to assess whether spending on IT contributes to OC in a sustained fashion.

We also estimate expression (10), which is a variant of expression (9), by using the preceding year's IT expenditures as well as the current year's change in IT expenditures over the preceding year. ${ }^{19}$

$$
\begin{aligned}
\log \left(\mathrm{OC}_{i t}\right)= & a_{0}+a_{1}[\text { Year dummies }]+a_{2} \mathrm{MKS}_{i t}+a_{3} \log \left(\mathrm{IT}_{i, t-1}\right) \\
& +a_{4}\left[\log \left(\mathrm{IT}_{i t}\right)-\log \left(\mathrm{IT}_{i, t-1}\right)\right]+e_{i t},
\end{aligned}
$$

where all variables are defined as in expression (9).

Table 3.3, panel A, provides the descriptive statistics of IT, OC, and market share (MKS) for the Information Week sample. The mean (median) IT expenditure is $\$ 192(\$ 78)$ million, with a minimum of $\$ 1$ million and a maximum of $\$ 4.3$ billion. Thus, the sample includes a cross section of companies that span a broad range of IT expenditures. Similarly, the mean (median) MKS is 5.8 percent ( 2.8 percent), with a minimum of 0.006 percent and a maximum of 75 percent, indicating that the sample includes a cross section of companies vis-à-vis market share. Table 3.3, panel $\mathrm{B}$, provides the Spearman rank correlations among OC, IT, lagged IT, and MKS. Our measure of organization capital is highly correlated with both the current IT spending as well as the lagged IT spending (correlation coefficients of 0.54 and 0.51 for current and lagged IT expenditures, respectively). This provides initial evidence that IT spending is associated with building organization capital.

Table 3.3, panel C, provides estimates of expressions (9) and (10). The coefficient of MKS is, as expected, positive and highly significant. The coefficients of both the prior year's IT expenditures and the current year's change in IT expenditures are positive and highly significant, indicating that information technology is a major contributor to organization capital, as captured by our measure. Table 3.3, panel D, provides the estimates of expressions (9) and (10) when the sample is partitioned into companies with yearly high, medium, and low market-to-book values. The marketbook ratio, namely the ratio of the firm's value in the capital market to its

19. We do not include the current value of information technology expenditure in expression (9) because $\mathrm{IT}_{i t}$ and $\mathrm{IT}_{i(t-1)}$ are highly correlated (see table 3.3, panel B). 


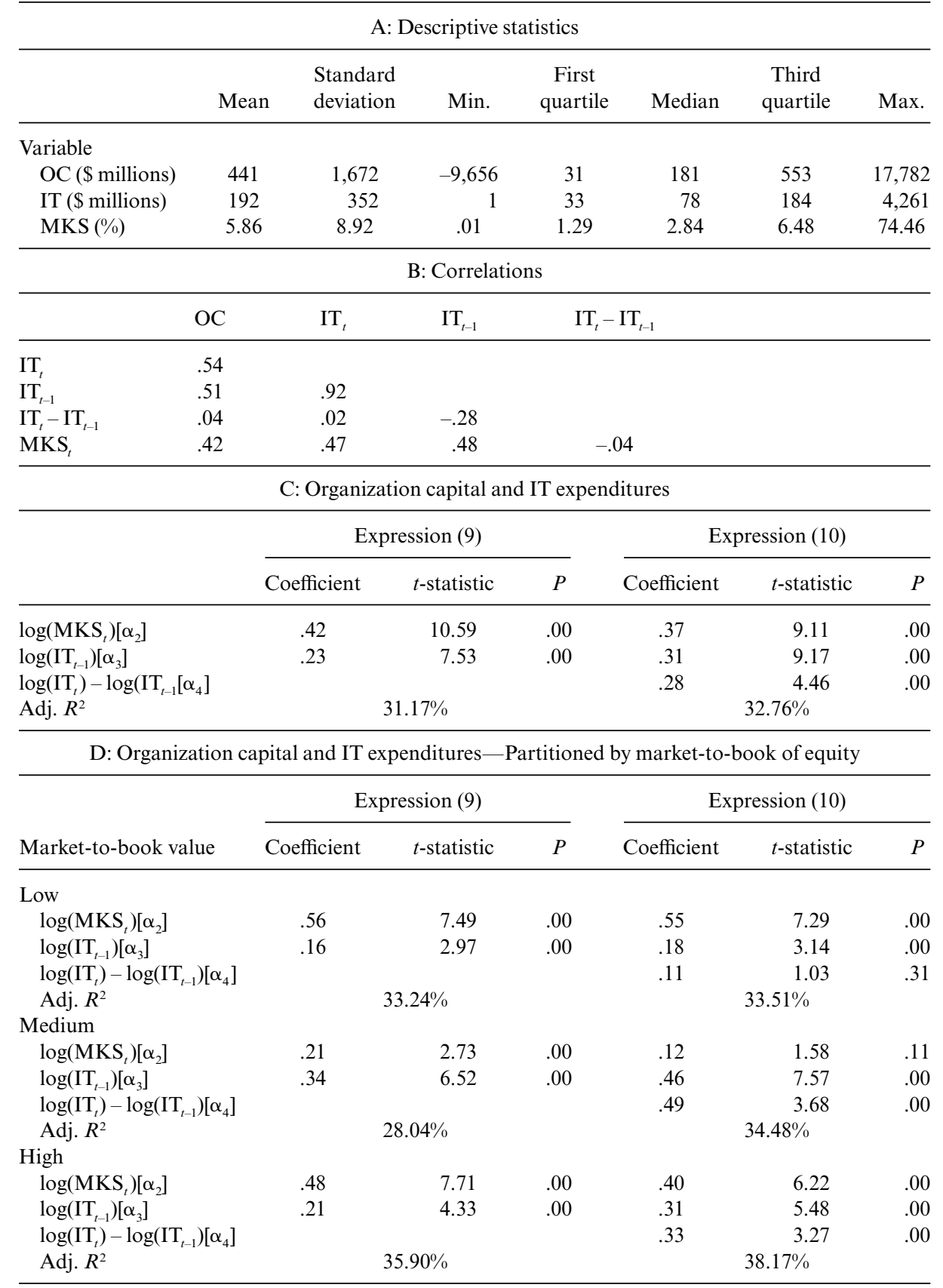

(continued) 
Table 3.3

(continued)

Notes: The numbers in Panel B are the Spearman rank correlation coefficients. The low, medium, and high market-to-book value of equity groups contain the bottom, middle, and top one-third of the observations sorted each year based on the market-to-book values of equity, respectively. The Information Week sample contains 1,818 firm-years, spanning 1991-97. $\mathrm{OC}_{i t}$ is the abnormal output computed as the predicted value of sales obtained by estimating expression (4) and the predicted value of sales with asset productivities alone in estimates of expression (4), i.e., expression (8). $\mathrm{MKS}_{i t}$ is the percentage of market share of firm $i$ in year $t$ computed for the 12 industry groups, $\mathrm{MKS}_{i m t}=\mathrm{SALE}_{i m t} / \Sigma_{j} \mathrm{SALE}_{i m t}$ where firm $i$ belongs to the industry group $m$ and the sum of sales is over all firms in the industry group $m$. IT is the information technology expenditure of firm $i$ in year $t$ as reported in the Information Week 500 survey.

value on the balance sheet - the latter reflecting primarily physical and financial assets - conveys investors' assessment of the firm's assets that are missing from its balance sheet (primarily intangible assets). Accordingly, high market-to-book value companies are intangible intensive- that is, rich in organization capital. The estimates of expressions (9) and (10) in panel D indeed show that IT expenditures are much more strongly associated with organization capital - higher values of the IT regression coefficients - for the group with high market-book ratios than for those with low market-book ratios, providing additional validity for our measure of organization capital.

\subsection{Organization Capital and Equity Valuation}

Having developed an estimate of organization capital, we now examine its validity by incorporating the measure in a widely used equity (stock) valuation model. This model (Preinreich, 1938; Ohlson 1995) relates the firm's stock price to its assets in place (property, plant, inventory, etc., minus liabilities) plus its growth potential, which is measured by the firm's future abnormal earnings. These are the earnings in excess of the required rate of return on assets (cost of capital). This model thus relates the value of the firm to its existing assets plus the future abnormal earning, or growth potential, expected from these assets:

$$
V_{i t}=\mathrm{BV}_{i t}+\mathrm{RE}_{i t} \text {, that is, } V_{i t}-\mathrm{BV}_{i t}=\mathrm{RE}_{i t},
$$

where $V_{i t}$ is firm $i$ 's market value at the end of year $t, \mathrm{BV}_{i t}$ is its book value (balance sheet value of assets minus liabilities) at the end of year $t$, representing assets in place, and $\mathrm{RE}_{i t}$ is firm $i$ 's present value of abnormal earnings at the end of year $t$ (growth potential). The right-hand rearrangement of expression (11) shows that the difference between market value and the value of assets-in-place is equal to the present value of abnormal earnings. ${ }^{20}$

Section 3.2 mentions organization capital as an unmeasured resource,

20. The familiar Tobin's $q$ ratio, used to assess a firm's investment opportunities, relates the firm's market value to replacement cost of assets. The latter is usually proxied by book value 
since it is not reflected in firms' balance sheets and is therefore absent from $\mathrm{BV}$ in equation (11). Hence, if our measure of organization capital captures important elements of the firm's future abnormal earnings potential, then it should be associated with the difference between the market and the book value of equity (expression [11]). Accordingly, our first validation test of the measure of organization capital is to estimate the following regression:

$$
\frac{\left(\mathrm{MV}_{i t}-\mathrm{BV}_{i t}\right)}{\mathrm{SALE}_{i t}}=q_{0}+q_{1}\left(\frac{\text { Year dummies }}{\mathrm{SALE}_{i t}}\right)+b_{1}\left(\frac{\mathrm{OC}_{i t}}{\mathrm{SALE}_{i t}}\right)+e_{i t},
$$

where $\mathrm{MV}_{i t}$ is firm $i$ 's market value of equity three months after the end of fiscal year $t, \mathrm{BV}_{i t}$ is firm $i$ 's book value of equity at the end of year $t, \mathrm{OC}_{i t}$ is the firm's contribution of organization capital to sales (expression [8]), and $\mathrm{SALE}_{i t}$ is the sales of firm $i$ in fiscal year $t .{ }^{21}$ We scale (deflate) all the variables by SALE to control for size effects. ${ }^{22}$ Note that MV and BV in expression (12) are stock variables, whereas $\mathrm{OC}$ is a flow variable (contribution of organization capital to annual sales). The estimate of $b_{1}$ obtained from expression (12) will therefore indicate the horizon over which investors capitalize organization capital.

The market value of equity is computed as the stock price multiplied by the number of common shares outstanding, obtained from the Center for Research on Stock Prices (CRSP) database. Financial data on book value (Compustat data item no. 11) were obtained from Compustat. Our estimations omitted firms with negative book value of equity. The sample contains 44,073 firm-year observations, spanning 1978-2002.

Table 3.4, panel A, provides descriptive statistics; panel B presents the estimates of expression (12). The adjusted $R^{2}$ value for the regression is approximately 24 percent, which indicates that $\mathrm{OC}$ by itself explains a quarter of the cross-sectional variation in the difference between market and book values of equity. This suggests that $\mathrm{OC}$ is strongly related to the firm's capacity to generate future abnormal earnings, or growth. The coefficient on $\mathrm{OC}$ is 2.26 , indicating that the contribution of organization capital in a given year to the present value of future abnormal earnings lasts for about three years, using a discount rate of 12 percent (i.e., $[1 /(1.12)]+\left[1 /(1.12)^{2}\right]$ $\left.+\left[1 /(1.12)^{3}\right]=2.40\right)$. This is consistent with the observation in the Xerox example (figure 3.1) that $\mathrm{OC}$ leads the stock price by about two years.

Table 3.4, panel C, provides the estimates of expression (12) for the high,

of assets, given difficulties in estimating replacement costs. The right-hand arrangement of expression (11) is Tobin's $q$ as a difference, rather than a ratio. The gap between market and book value, representing investment opportunities in the $q$ theory, is manifested in expression (11) by $\mathrm{RE}_{i t}$, the present value of abnormal earnings.

21. The market value of firm $i, \mathrm{MV}_{i t}$, is measured three months after the end of the year to allow stock prices to reflect the financial results of year $t$, which have to be publicly disclosed during the ninety days after the end of the year.

22. See Brown, Lo, and Lys (1999) for the appropriateness of using sales as the scaling variable. 


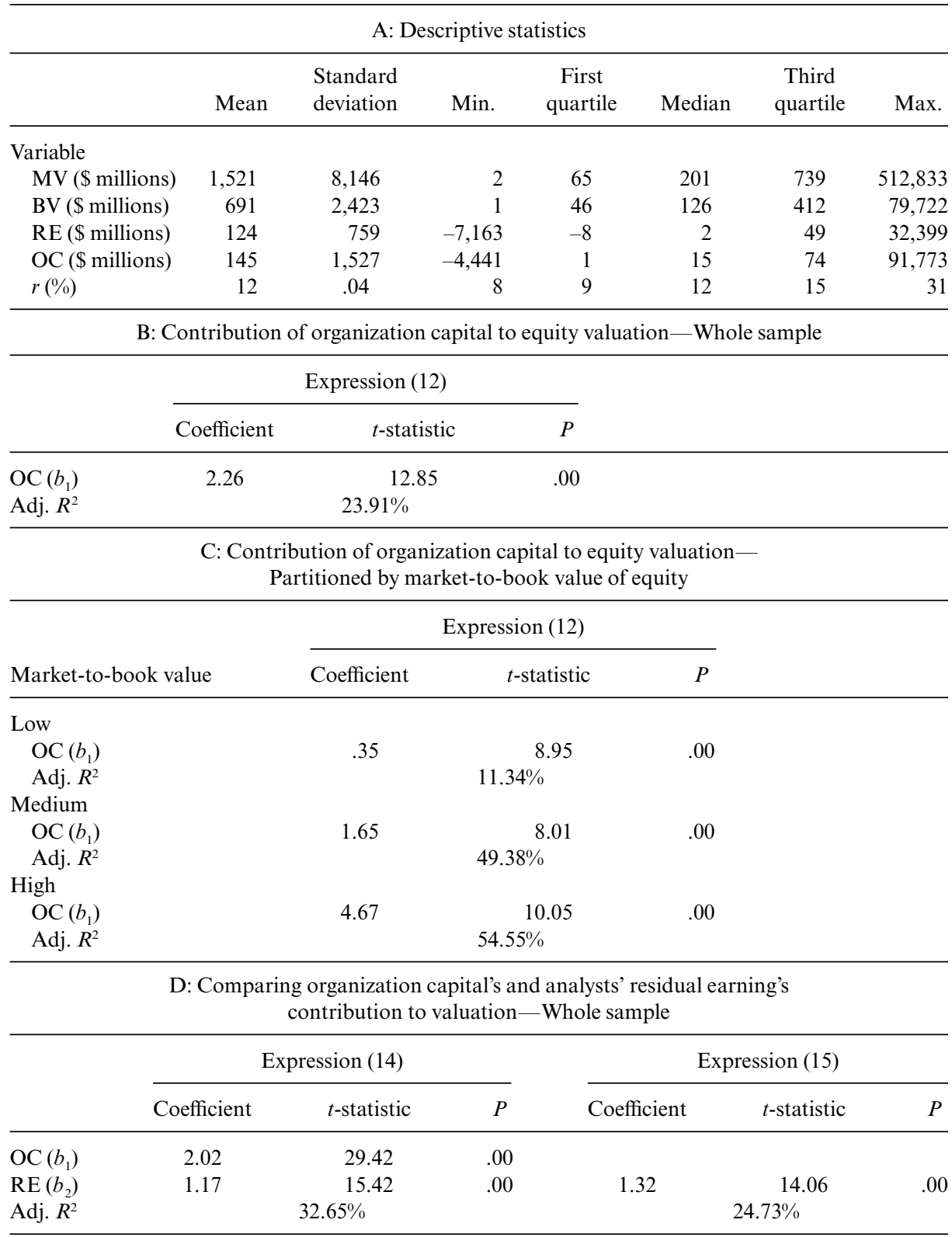


E: Comparing organization capital's and analysts' residual earning's contribution to valuationPartitioned by market-to-book value of equity

\begin{tabular}{|c|c|c|c|c|c|c|}
\hline \multirow[b]{2}{*}{ Market-to-book value } & \multicolumn{3}{|c|}{ Expression (14) } & \multicolumn{3}{|c|}{ Expression (15) } \\
\hline & Coefficient & $t$-statistic & $P$ & Coefficient & $t$-statistic & $P$ \\
\hline \multicolumn{7}{|l|}{ Low } \\
\hline $\mathrm{OC}\left(b_{1}\right)$ & .32 & 7.15 & .00 & & & \\
\hline $\operatorname{RE}\left(b_{2}\right)$ & .41 & 8.25 & .00 & .45 & 9.61 & .00 \\
\hline Adj. $R^{2}$ & \multicolumn{3}{|c|}{$24.79 \%$} & \multicolumn{3}{|c|}{$15.09 \%$} \\
\hline \multicolumn{7}{|l|}{ Medium } \\
\hline $\mathrm{OC}\left(b_{1}\right)$ & 1.52 & 17.18 & .00 & & & \\
\hline $\operatorname{RE}\left(b_{2}\right)$ & .64 & 7.58 & .00 & 1.02 & 9.34 & .00 \\
\hline Adj. $R^{2}$ & \multicolumn{3}{|c|}{$52.30 \%$} & \multicolumn{3}{|c|}{$22.50 \%$} \\
\hline \multicolumn{7}{|l|}{ High } \\
\hline OC $\left(b_{1}\right)$ & 3.15 & 21.39 & .00 & & & \\
\hline $\operatorname{RE}\left(b_{2}\right)$ & 2.62 & 24.71 & .00 & 3.73 & 30.59 & .00 \\
\hline Adj. $R^{2}$ & \multicolumn{3}{|c|}{$55.25 \%$} & \multicolumn{3}{|c|}{$32.56 \%$} \\
\hline
\end{tabular}

Notes: The $t$-statistic is the White's heteroskedasticity adjusted $t$-statistic. The low, medium, and high market-to-book value of equity groups contain the bottom, middle, and top one-third of the observations sorted each year based on the market-to-book values of equity, respectively. The sample contains 44,073 firm-year observations spanning 1978-2002. MV is the market value four months subsequent to the fiscal year-end; BV is the stockholders' equity; the discount rate $(r)$ is computed as beta times risk premium of 5.5 percent plus the twelve-month treasury bill rate. The beta value is obtained from CAPM using the monthly returns for firm $i$ from year $(t-5)$ to $(t-1)$. RE is the sum over five years of the discounted abnormal earnings plus a terminal value. Specifically, $\mathrm{RE}_{i t}=\Sigma_{k=1,5}\left[\mathrm{FE}_{i k t}-\mathrm{r}_{i t} \mathrm{BV}_{i,(k-1) t}\right]\left(1+r_{i t}\right)^{-k}$ $+\left[\mathrm{FE}_{i 6 t}-r_{i t} \mathrm{BV}_{i 5 t}\right]\left(r_{i t}-g_{i t}\right)^{-1}\left(1+r_{i t}\right)^{-5}$, where $g_{i t}$ is the growth in $\left[\mathrm{FE}_{i 6 t}-r_{i t} \mathrm{BV}_{i 5 t}\right]$. $\mathrm{FE}_{i k t}$ is the consensus analysts' earnings forecast $k$ years ahead for firm $i$, four months after the fiscal year $t$; $V_{i t}$ is the value of equity computed as the sum of $\mathrm{RE}_{i t}$ and $\mathrm{BV}_{i t} ; \mathrm{OC}_{i t}$ is the abnormal output computed as the predicted value of sales obtained by estimating expression (4) and the predicted value of sales with asset productivities alone in expression (4) estimates (i.e., expression [8]).

medium, and low market-to-book value of equity subsamples. As noted in section 3.4, companies with high market-to-book values are more intangible intensive, and hence the contribution of OC to future abnormal earnings should be greater. The estimates are consistent with this notion: for the high market-to-book firms, the coefficient on OC is 4.67, which suggests that the contribution of organization capital to future abnormal earnings lasts for about five years, using a discount rate of 12 percent, whereas, for the medium market-to-book firms, the OC contribution to future abnormal earnings lasts for about two years (and less than a year for low marketto-book firms). We thus conclude that our measure of organization capital captures a major component of the firm's intangibles assets, or growth potential, as reflected by the gap between the market and book (accounting) values of public companies.

Since organization capital is a major contributor to future earnings, and hence OC will be partially or fully subsumed by the present value of 
abnormal earnings (RE), we omitted $\mathrm{RE}_{i t}$ from the regression in expression (12). We now introduce a widely used proxy for future earnings-financial analysts' forecasts of earnings - into the valuation model. ${ }^{23}$ In essence, we wish to test the extent to which financial analysts, the major information intermediaries in capital markets, comprehend the value and profit implications of organization capital in their analyses and consequent earnings forecasts.

Accordingly, we compute the present value of the firm's abnormal earnings as the sum of two components: the present value of abnormal earnings in the next five years, based on explicit analysts' forecasts of annual earnings, plus the present value of abnormal earnings from year six to infinity. The overall present value of abnormal earnings is defined thus:

$$
\begin{aligned}
\mathrm{RE}_{i t}= & k_{=1,5}\left[\mathrm{FE}_{i k t}-r_{i t} \mathrm{BV}_{i(k-1) t}\right]\left(1+r_{i t}\right)^{-k} \\
& +\left(\mathrm{FE}_{i 6 t}-r_{i t} \mathrm{BV}_{i 5 t}\right)\left(r_{i t}-g_{i t}\right)^{-1}\left(1+r_{i t}\right)^{-5},
\end{aligned}
$$

where $\mathrm{FE}_{i k t}$ is the consensus analysts' earnings forecast for firm $i, k$ years ahead, made four months after the end of fiscal year $t$ (to allow financial analysts access to the annual report of year $t) ; r_{i t}$ is the discount rate applied to future earnings; $\mathrm{BV}_{i t}$ is the book value (net assets) of firm $i$ at the end of year $t\left(\mathrm{BV}_{i k t}=\mathrm{BV}_{i,[k-1] t}+\mathrm{FE}_{i k t}-\mathrm{DIV}_{i k t}\right) ; \mathrm{DIV}_{i t}$ is the dividend the firm paid in year $t$; and $g_{i t}$ is the growth rate of abnormal earnings in year six $\left(\mathrm{FE}_{i 6 t}-\right.$ $\left.r_{i t} \mathrm{BV}_{i 5 t}\right){ }^{24}$ Thus, residual earnings for each future year-the difference between analysts' earnings forecast for that year (FE) and a charge for the cost of equity $(r \mathrm{BV})$ - are predicted for each company for the next five years, followed by a terminal value, based on a constant growth expression. We estimate firm-specific discount rate, $r_{i t}$, using the capital asset pricing model (CAPM) with a beta (systematic risk) indicator estimated in a conventional fashion (regressing the firm's monthly stock returns on the market return), using returns from the preceding sixty months. The discount rate is then set equal to the twelve-month Treasury bill rate (the riskless rate) plus the estimated beta multiplied by an equity risk premium of 5.5 percent. ${ }^{25}$

To examine the extent to which financial analysts incorporate elements of the organization capital estimate, $\mathrm{OC}$, into their future earnings forecasts, we estimate the following two expressions:

23. Commercially available forecasts of future earnings are provided by various sources for most public companies for one, two, and sometimes three years out, as well as long-term (five years out) growth rates of earnings. We obtained analysts' consensus (mean) earnings forecasts (for multiple forecasts per firm) and long-term growth estimates from I/B/E/S (First Call).

24. The growth rate from year five on, $g_{i t}$, is set equal to $r_{i t}$ minus 3 percent, if $g_{i t}>\left(r_{i t}-0.03\right)$. We used the current dividend payout ratio (dividends to earnings) to estimate expected dividends and winsorized the dividend payout ratio at 10 percent if the current dividend payout ratio exceeded 10 percent.

25. We obtain similar results when using a constant discount rate of either 10 percent or 12 percent for all firms. 


$$
\begin{aligned}
\frac{\left(\mathrm{MV}_{i t}-\mathrm{BV}_{i t}\right)}{\mathrm{SALE}_{i t}}= & q_{0}+q_{1}\left(\frac{\text { Year dummies }}{\mathrm{SALE}_{i t}}\right)+b_{1}\left(\frac{\mathrm{OC}_{i t}}{\mathrm{SALE}_{i t}}\right) \\
& +b_{2}\left(\frac{\mathrm{RE}_{i t}}{\mathrm{SALE}_{i t}}\right)+e_{i t},
\end{aligned}
$$

and

$$
\frac{\left(\mathrm{MV}_{i t}-\mathrm{BV}_{i t}\right)}{\mathrm{SALE}_{i t}}=q_{0}+q_{1}\left(\frac{\text { Year dummies }}{\mathrm{SALE}_{i t}}\right)+b_{2}\left(\frac{\mathrm{RE}_{i t}}{\mathrm{SALE}_{i t}}\right)+e_{i t},
$$

where all variables retain their previous definitions. Expression (15) provides the estimation of the valuation model without organization capital, OC, whereas expression (14) includes the organization capital. If analysts fully incorporate the contribution of organization capital to future earnings in their earnings forecasts, then OC will be subsumed in RE, and the coefficient on OC in expression (14) will be zero. Conversely, if analysts do not fully incorporate the effect of organization capital in their earnings forecasts, the coefficient on OC $\left(b_{1}\right)$ will be positive, and the explanatory power of expression (14) will be higher than that of expression (15). In this manner, we assess analysts' ability to value firms' organization capital.

Table 3.4, panel D, provides estimates of expressions (14) and (15), indicating that the addition of organization capital (OC) to the valuation expression (14) substantially improves the explanatory power: from 24 percent (adjusted $R^{2}$ of expression [15]) to 32 percent (adjusted $R^{2}$ of expression [14]). The coefficient estimate on the flow variable OC is 2.02 and is highly statistically significant, indicating that financial analysts fail to capture a major asset (organization capital) that contributes to future profitability.

Table 3.4, panel E, provides estimates of expressions (14) and (15) when the sample is partitioned into three groups of firms ranked by market-tobook value of equity. For all partitions, the OC measure improves the explanatory power of the gap between market and book values. However, OC provides the largest improvement in explanatory power for the medium and high market-to-book groups: the adjusted $R^{2}$ of expression (14) is 52 percent (medium) and 55 percent (high) versus 22 percent and 32 percent for expression (15), respectively. This suggests that financial analysts, the highly influential information intermediaries in capital markets, fail to fully comprehend the value and impact of organization capital, and that this failure is particularly acute for high-growth (high market-to-book) firms.

The adjusted- $R^{2}$ measures of the yearly estimates of expressions (14) and (15) are presented in figure 3.2: the top line is the adjusted- $R^{2}$ value of the model that includes organization capital (expression [14]), and the bottom line is for the model without organization capital (expression [15]). The figure indicates that the incremental contribution of our estimate of organi- 


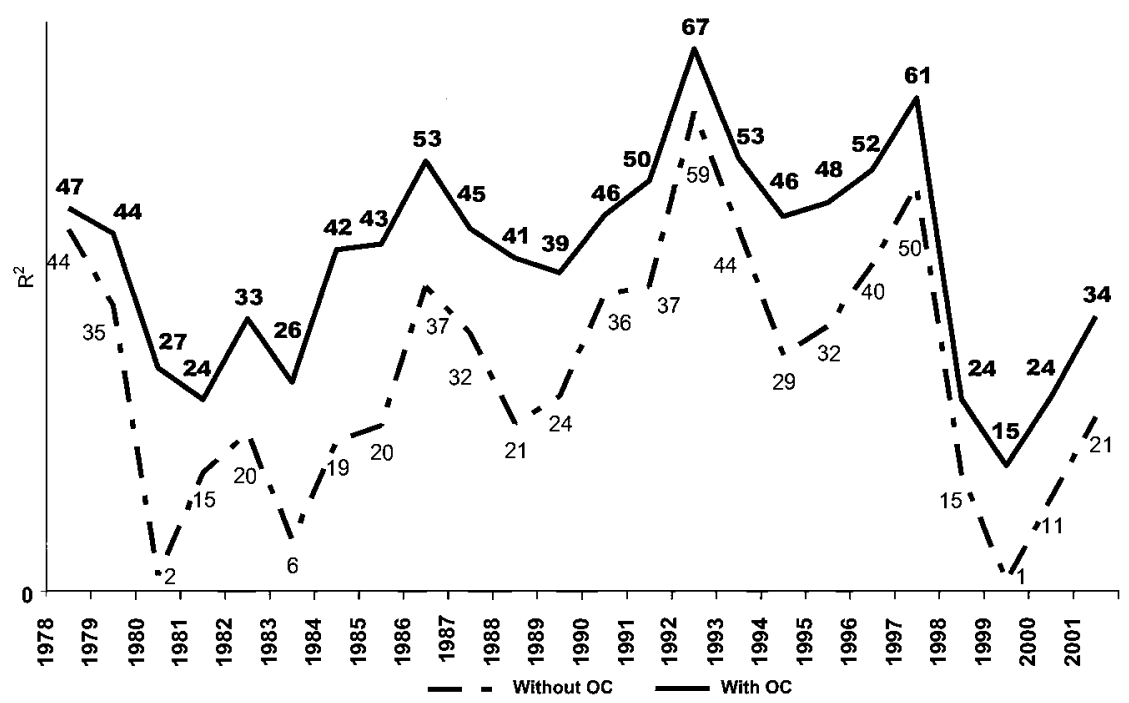

Fig. 3.2 Explanatory power of expressions (14) and (15)

zation capital over the information in the present value of residual earnings (the horizontal difference between the lines) was positive throughout the period, but has decreased during the late 1990s. The probable reason: financial analysts, whose forecasts determine RE in expression (15), are becoming increasingly sophisticated in incorporating the benefits of organization capital in their earnings forecasts.

\subsection{Concluding Remarks}

Organization capital is the major idiosyncratic resource that affects performance and growth of firms. However, this resource is not measured internally by companies, nor is it reported to capital markets. In this study, we develop a firm-specific measure of organization capital and estimate it for a large sample of publicly traded companies. To validate our measure, we examine the association between information technology expenditures and organization capital and find that IT is highly associated with organization capital. We then test the validity of our measure within a widely used investment valuation model and show that it contributes significantly to the explanation of market values of firms, beyond the traditional indicators of assets in place (book value) and expected abnormal earnings (growth potential). We also document that financial analysts, the major information intermediaries in capital markets, fail to fully comprehend the value of firms' organization capital, probably because of the absence of relevant information on this resource in corporate financial reports (e.g., no data on 
IT expenditures, employee training, brand enhancement activities, etc.). Our measure of organization capital is, therefore, expected to improve both resource allocation within companies and investors' valuations.

\section{Appendix}

\section{Industry Definitions ${ }^{26}$}

\section{SIC codes}

1 Consumer nondurables: food, tobacco, textiles, apparel, leather, toys

2 Consumer durables: cars, TVs, furniture, household appliances

3 Manufacturing: machinery, trucks, planes, office furniture, paper, commercial printing

4 Energy, oil, gas, and coal extraction and products

5 Chemicals and allied products

6 Business equipment: computers, software, and electronic equipment

7 Telecom, telephone, and television transmission

8 Utilities

9 Wholesale, retail, and some services (laundries, repair shops)

10 Health care, medical equipment, and drugs

11 Money, finance

12 Other: mines, construction, building materials, transportation, hotels, business services, entertainment

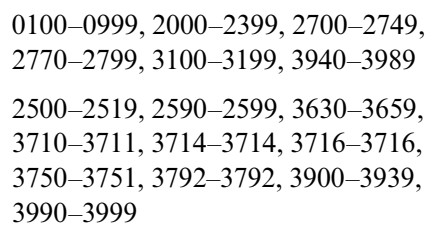

0100-0999, 2000-2399, 2700-2749, 2770-2799, 3100-3199, 3940-3989

2500-2519, 2590-2599, 3630-3659, 3710-3711, 3714-3714, 3716-3716, 3750-3751, 3792-3792, 3900-3939, 3990-3999

2520-2589, 2600-2699, 2750-2769, 3000-3099, 3200-3569, 3580-3629, 3700-3709, 3712-3713, 3715-3715, 3717-3749, 3752-3791, 3793-3799, 3830-3839, 3860-3899

1200-1399, 2900-2999

2800-2829, 2840-2899

3570-3579, 3660-3692, 3694-3699, 3810-3829, 7370-7379

4800-4899

4900-4949

5000-5999, 7200-7299, 7600-7699

2830-2839, 3693-3693, 3840-3859, 8000-8099

6000-6999

All other SIC codes

\section{References}

Aghion, P., and P. W. Howitt. 1998. Endogenous growth theory. Cambridge: MIT Press.

26. Based on Fama and French $(1988,1997)$. 
Arrow, K. J. 1962. The economic implications of learning by doing. Review of Economic Studies 29 (3): 155-73.

Atkeson, A., and P. J. Kehoe. 2002. Measuring organizational capital. NBER Working Paper no. 8722. Cambridge, MA: National Bureau of Economic Research.

Becker, G. S. 1993. Human capital: A theoretical and empirical analysis, with special reference to education. Chicago: University of Chicago Press.

Brown, S., K. Lo, and T. Lys. 1999. Use of $R^{2}$ in accounting research: Measuring changes in value relevance over the last four decades. Journal of Accounting and Economics 28 (2): 83-116.

Brynjolfsson, E., and L. Hitt. 1996. Paradox lost? Firm-level evidence on the returns to information systems spending. Management Science 42 (4): 541-58.

Brynjolfsson, E., and S. Yang. 1999. The intangible benefits and costs of computer investments: Evidence from the financial markets. Massachusetts Institute of Technology, Sloan School of Management. Working Paper.

Chan, L. K. C., J. Lakonishok, and T. Sougiannis. 2001. The stock market valuation of research and development expenditures. Journal of Finance 56 (6): 2431-56.

Ericson, R., and A. Pakes. 1995. Markov-perfect industry dynamics: A framework for empirical work. Review of Economic Studies 61 (1): 53-82.

Evenson, R. E., and L. E. Westphal. 1995. Technological change and technological strategy. In Handbook of development economics, ed. J. Behrman and T. N. Srinivasan, 2211-98. Amsterdam: North-Holland.

Fama, E. F., and K. R. French. 1988. Permanent and temporary components of stock prices. Journal of Political Economy 96 (2): 246-73.

94.

Gordon, R. 2000. Does the "new economy" measure up to the great inventions of the past? Journal of Economic Perspectives 14 (4): 49-74.

Gordon, R., and M. N. Baily. 1993. The jobless recovery: Does it signal a new era of productivity-led growth? Brookings Papers on Economic Activity, Issue no. 1: 271-316.

Griliches, Z., and J. Mairesse. 2000. Production functions: The search for identification. NBER Working Paper no. 5067. Cambridge, MA: National Bureau of Economic Research.

Hall, B. H. 1993. Industrial research during the 1980s: Did the rate of return fall? Brookings Papers on Economic Activity, Microeconomics: 289-330.

Hall, R. E. 2000. E-capital: The link between the stock market and the labor market in the 1990s. Stanford University, Hoover Institution and Department of Economics. Working Paper.

Jovanovic, B. 1979. Job matching and the theory of turnover. Journal of Political Economy 87 (5): 972-90.

Lev, B., and T. Sougiannis. 1996. The capitalization, amortization, and valuerelevance of R\&D. Journal of Accounting and Economics 21:107-38.

McKinsey Global Institute. 2002. Learning to love recessions. The McKinsey Quarterly, no. 2:4-5.

Ohlson, J. Earnings, book values, and dividends in security valuation. Contemporary Accounting Research 11 (2): 1-23.

Preinreich, G. A. D. 1938. Annual survey of economic theory: The theory of depreciation. Econometrica 6 (3): 219-41.

Prescott, E. C., and M. Visscher. 1980. Organization capital. Journal of Political Economy 88 (3): 366-82.

Rosen, S. 1972. Learning by experience as joint production. Quarterly Journal of Economics 86 (3): 366-82. 
Solow, R. 1957. Technical change and the aggregate production function. Review of Economics and Statistics 39 (3): 312-20.

Tomer, J. F. 1987. Organizational capital: The path to higher productivity and wellbeing. New York: Praeger.

\section{Comment Timothy F. Bresnahan}

The goal of this paper is an important one. The authors set out to define "organizational capital," to measure it, and to see whether capital markets properly value it in large companies. The importance arises from several conjectures that I and many others share with the authors. Few doubt that the organization of firms is among the determinants of productivity and productivity growth. Few doubt the value of a set of systematic measures in this area. Few doubt that reorganization of firms arising from use of information technology will leave customers better off and successful firms with higher market shares. And finally, few doubt that the widespread assertion of a "new economy" form of organizational capital gave capital markets an extraordinarily difficult valuation problem in the late 1990s. All these conjectures lead us toward goals like those in this paper.

The paper's methods to measure organizational capital center on production function residuals at the firm level. The authors focus on large, publicly traded firms. In the first approach, a Cobb-Douglas production function, with $R \& D$ as one of the inputs, is estimated in first differences with firm dummies. The residual is cumulated and called organizational capital.

In this approach a high rate of growth of firm sales, above and beyond growth in employment, physical capital, and R\&D capital, measures the rate of growth of organization capital. The firm-specific effects are modeled as moving over time. At year $t$, the measure of organizational capital growth comes from the model run on years $t-4$ through $t$. The next year, the measure of organizational capital growth comes from the model run on years $t-3$ to $t+1$, and so on.

In a second approach, the firm's sales, general, and administrative costs (SGA) are taken to be a measure of expenditures to gain organizational capital (OC). A production function more general than the Cobb-Douglas is estimated; all the Cobb-Douglas parameters are allowed to vary with SGA. The measure of OC comes from comparing predicted sales at SGA $=0$ to the actuals. Thus, in the second version, a productivity residual is projected onto SGA and the interaction of SGA with other inputs and called OC.

Timothy F. Bresnahan is the Landau Professor of Technology in the Economy at Stanford University and a research associate of the National Bureau of Economic Research. 
With those two sets of estimates in hand, the paper examines several economic questions. The authors seek to document the size and growth of measured OC in the class of firms they study. They investigate whether measured OC is correlated with any of several variables associated with theories of organizational improvement. These include market share, computer investment, and administrative expenses. Finally, the authors examine the stock market valuation of measured OC using standard finance methods. They are interested in both the degree to which the stock market values companies that have high measured $\mathrm{OC}$ and the question of whether the stock market over- or undervalues such companies.

The particular methods choices determine the empirical content of the measures of OC. Much trouble arises because it is difficult to become convinced that production function residuals at the firm level measure OC.

I will begin with a discussion of what we have learned from earlier research that uses methods related to this paper. I will then turn to the main results and their interpretation. Potential worries about whether the object that has been measured might be precisely something called "organizational capital" grow as we examine the authors' tests of organizational theories, their growth accounting, and their capital market investigations. I will go on to talk about the conceptual and data limitations that are holding back this entire field, not just this paper.

\section{Methods I: Residuals}

The most important modeling choice in the paper is to measure OC either as a production function residual at the firm level or as the portion of a production function residual that is explained by variation in SGA.

In general, estimating production functions is not a happy task. It is very difficult to succeed in that effort either at the aggregate level or at the individual firm level. At the aggregate level, it is difficult to get the output deflators right, so that real output - the dependent variable in the production function - is always suspect. At the firm level, that particular problem is somewhat ameliorated. Firms that have some hard-to-measure competitive advantage, such as better products, will tend to have larger market shares in industry equilibrium. They will thus tend to have larger nominal sales. To the degree it comes from a superior production technology that is uncorrelated with other factors of production, production function estimates will capture it.

That is the basic logic under which this paper might be right. Organization capital is likely to be reflected in superior products, especially in the service sectors. Thus, looking at a firm-level productivity residual may well capture OC if it is there.

The downside of working at the firm level is that firms are highly heterogeneous. Unobserved heterogeneity in firm-level productivity or demand makes estimating the production function difficult. Even with panel data on 
firms, it can be hard to learn the firm-level production function, especially if one is hoping to tell apart selection, endogeneity in the inputs, and true advantages to the firm in better productivity. ${ }^{1}$ The firm-level productivity residual can measure, inter alia, unobserved demand and supply movements at the firm and industry level and the firm's response to those shocks.

This is the downside of the logic behind the measurement strategy of this paper. The firm-level production function residual may well contain the effects of OC if it is there, but it will also contain everything else about how firms are different, or in different circumstances. The fundamental idea of the paper is a relative one. Those firms with more output growth per unit input growth relative to other firms are labeled as high-measured-OC firms.

On balance, I suspect firm-level analysis is likely the least bad for the purposes of this paper, which is about firms, but it is important to recall what it can and cannot do. The paper's calculations, which make no effort to control for the most familiar measurement problems in this area, are likely suspect.

\section{Methods II: Organizations}

The second fundamental point to make about methods relates to the measurement of organizations. The paper does not measure firm organization.

There are no measures of hierarchy or its absence; no measures of centralization or decentralization; no measures of the degree to which workers are on dynamic incentive contracts; no measures of the divisional structure of the firm; no measures of the workplace organization in productive units; no measures of corporate culture; and no measures of the role of management. In short, there are no measures suggested by the theory or empirical literatures in empirical or theoretical organizational behavior or the economics of organizations. ${ }^{2}$

The paper does use the firm's expenditures on SGA as a predictor of the production function residual. The implicit story is that a firm that spends more money on administration (the " $\mathrm{A}$ " in SGA) is organizing itself better.

For a number of reasons, the dollars spent by a firm on SGA have only a very distant linkage to "organizational capital" in the sense of the paper. The most direct point is that a badly organized firm may need more managers, not fewer. A separate point is that SGA includes marketing expenditures as well as managerial ones.

1. While these arguments are longstanding, perhaps the clearest sense of the trade-offs can be found in Griliches and Mairesse (1998). That paper reports an interesting effort to deal with the problem, as does one by Olley and Pakes (1996), with a nonparametric selection model.

2. A summary of the relevant theory can be found in Milgrom and Roberts (1992). Recent empirical and theoretical developments were reported at the NBER Organizational Economics Conference: see http://www.nber.org/ confer/2002/orgec02/program.html. 
There are also serious econometric issues associated with SGA. Of course it is possible that the SGA coefficients measure managers' organizational contribution. To the extent that organizing the firm is costly and these costs are reflected in SGA, that would be the right interpretation. There is a problem with the implicit identifying assumption in that (most positive) case. If firms with higher SGA are more productive, are firms with lower SGA making mistakes?

More serious problems arise when either SGA is not the only driver of improved organization or it is not given by some exogenous process. Suppose that there are organizational improvements that do not lead to more expenditure on SGA, such as improvements in workplace organization, streamlining bureaucracy, improvements in the quality of decisions of their communications, and so on. The paper will not measure these.

The paper will, incorrectly, measure correlations between SGA and the firm residual that are not causal. If firms with looser budgets spend more on management salaries, for example, that will be measured as OC in this paper. Thus, an uptick in sales, part of which becomes management rents, is called OC.

My real point is that there is only so much that can be done with production function residuals. This paper labels a production function residual as OC. Sometimes, it uses only the part of the residual that can be predicted by SGA, or SGA interacted with the factors of production. It is always using a productivity residual, however.

An alternative approach would be to link outcomes at the firm level empirically to data that actually measure something about organizations. There are many approaches to that (see note 3 ). In recent work related to this paper, Erik Brynjolfsson, Lorin Hitt and I (Bresnahan, Brynjolfsson, and Hitt, 2002) have tested the hypothesis that investments in information technology are complementary to workplace organization. In our work, the organizational variables we use are measures of the way production workers are connected to the firm - how they are supervised, whether they work in teams, the nature of their in-house training, and so on. In my view, much of the reason to believe the conclusion that the results are specifically organizational depends on the use of these data. We are hardly alone in this. For example, Cockburn and Henderson (1998) have interesting measures of the organization of laboratories in pharmaceutical firms, related to the firms' ability to absorb scientific knowledge and turn it into profitable products.

One could go on in this vein for some time. Recent research has made some progress in measuring organizational features at the firm and industry level and relating them to economic outcomes, but there is still much work to be done. Much of the most promising work has used case study or historical methods. Statistical methods have crashed up against fundamental data limitations. This is not a problem of measuring residuals. 
Scholars who seek to measure organizational effectiveness using data on the structure of organizations, on incentives within the organization, on management, and so on-all the things that would be the beginnings of empirical correlates of organizational capital - do not typically use the same data used to study national economic growth. Indeed, most of the research literature in organizations goes forward without using any of the data resources of the federal statistical system at all, but is rather based in the hard work of scholars in business schools.

The issue is not, I hasten to add, that the people working in the federal statistical system are unaware of the changes in the organization of firms and industries that matter for modern economic growth. ${ }^{3}$ Nor is the problem that the federal statistical system fails to understand the importance of making data resources available to researchers for purposes of generating new knowledge. Like me, they recognize the value of a thriving empirical economic research program for future economic policymaking. The issue is simply one of resources.

\section{Results}

While the paper has a number of subsidiary results, the main results are as follows:

1. Measured organizational capital is large and makes a substantial contribution to the growth of firm output.

The size of measured OC is different in two methods used by the authors, but it is in either case a substantial fraction of physical or R\&D capital for the firms they study.

2. Measured OC is persistent at the firm level.

The paper reports the persistence of its measures of OC and finds that it is high. The paper also examines the underlying production function residuals themselves, finding them to be highly persistent. Thus, the persistence of measured OC is not an artifact of the particular time series process assumed by the authors.

3. Measured $\mathrm{OC}$ is correlated in the cross section with

a. Firm market share in its two-digit SIC industry

b. Firm expenditures on information technology

c. SGA (for the first OC measure)

4. Value in the stock market at the moment the authors' OC measure could be calculated.

5. Stock market gains after their OC measure could be calculated.

3. The federal statistical system has recently undertaken a very wise overhaul of the way it classifies establishments, of which an important part is recognizing some organizational issues. 
These last two results come from a standard financial markets valuation regression. The finding that $\mathrm{OC}$ predicts firm value is in a regression in which several other assets and analysts' forecasts are held fixed.

\section{Interpretation of Results}

The authors have made the tables, and any discussion naturally begins with their interpretation. It should not end there, however, as many of the substantive interpretations we find in this paper involve further unverified assumptions.

Findings 1 and 2, substantial measured organizational capital and substantially persistent measured OC, seem to me to be better labeled "assumptions" than "results." The paper reports that the contribution of organizational capital to the growth of sales is large. Since OC was measured as a residual (or a residual projected onto SGA) from a first-differenced production function, the contribution of OC to growth in output is an identity, not a result.

Similarly, the finding that measured OC is persistent at the firm level is the finding that a firm production function residual is persistent at the firm level. That well-known fact establishes that firms are different in ways that move slowly, not necessarily that the reason for that is OC.

The three subfindings under result 3 are interpreted by the authors as evidence that their economic interpretation is right. I am less convinced.

Findings $3 a, 3 b$, and $3 c$ establish that the production function residual is correlated with market share, IT budgets, and SGA. I have already talked about the SGA correlation. The interpretation the authors offer for the first two correlations is that improvements in OC improve firm competitive position and that OC and IT are complements. I agree with both of those economic conclusions but do not see any evidence for them in this paper.

The finding about market share seems to me to be simply a restatement of what the paper does. Positive production function residuals arise when a firm's sales rise more rapidly than its inputs. A firm will have a larger value of those residuals when, relative to other firms, its sales/input is rising rapidly. That could happen because the firm has grown more productive through a positive improvement in its organization, the authors' preferred interpretation, or because there has been an outward shock to the firm's demand for any reason, which would cause output and measured productivity to rise. There is a substantial literature that attempts to sort out these two different flows of causation in order to identify the part of the firm-level productivity residual that is in fact a shock to the production function. This paper interprets the entire correlation as productivity.

The finding about IT is one of a long series of findings that IT budgets are correlated with success at the firm level. The work of Erik Brynjolfsson, alone and with collaborators, has established this fairly clearly. In work that I did with Erik and Lorin Hitt, cited above, the correlation is very care- 
fully unpacked to learn how much of it is related to improvements in organization that lead to productivity improvements and how much reflects other flows of causation. There is no similar effort in this paper.

In short, I agree that improvements in organization at the firm level, often in recent years connected to IT, are an important area for productivity growth. What I don't see in this paper is an attractive measure of that or any evidence for it. The paper's complaint that "there exist no operational measures of firms' organizational capital" is still right.

\section{Capital Markets}

The paper goes on to show that high-measured-OC firms are (finding 4) more valuable in the stock market and (finding 5) get predictable stockmarket gains. The authors conclude that investors reward firms that have invested in OC before the returns on that capital are visible (4) but undervalue this capital (5).

The finding that high-measured-OC firms are more valuable in the contemporary stock market (4) follows from the measurements. Any economic interpretation of measured OC would likely lead to finding 4 -including the authors' interpretation, but also including any other.

Finding 5 is more interesting. Whenever stock market returns can be predicted in a regression, there is something to pay attention to. The undervaluation conclusion follows from the empirical finding that returns in stock prices can be econometrically predicted using the measure of OC. ${ }^{4}$

I am dubious about the economic conclusion. My doubt has its roots in two arguments, one about the sample period and the other about measured OC.

The sample period begins in the 1990s (for this exercise) and ends in 2000. That is a period of surprising sustained macroeconomic expansion. The capital markets appeared to base valuation of companies in this era at least in part on the view that the aggregate economy would continue to have surprising growth, and so that growth companies would continue to have good prospects. This is not an idea that was quite so important in the capital markets either earlier or, as we now know, later.

In general, this was a good period in which to have been holding equities in firms that grew with or faster than the aggregate economy. A bull market, in short. The authors' measures of OC are measures of relative company growth. When company sales per unit input rise, measured $\mathrm{OC}$ will rise.

So the evidence in this paper that there is a "misevaluation of organizational capital on the stock market" (or the need for a new risk factor) is this. Holding a portfolio of growth companies during the 1990s would have led

4. An alternative interpretation the authors offer is that this finding might point us toward "a new risk factor associated with organizational capital." I will treat that as part of their main interpretation. 
to extraordinary gains. It seems to me that there is a long step from that evidence to the conclusion that the capital markets undervalue "organizational capital."

Those remarks merely report what I hope is standard applied finance common sense. You could "show" by these methods that many different assets were "undervalued" in the 1990s. U.S. equities in general, for example, could be "shown" to be undervalued in that period by the methods used in this paper. Anyone who held U.S. equities through that time period earned good returns. The problem is, you are looking at a long bull market. You always do well buying stocks before a bull market. You also will always do particularly well buying high-measured-OC stocks before a bull market.

There are many, many plausible ways in which the U.S. stock market was getting valuation wrong in the 1990s. A bubble in which all equities were overvalued is one plausible way, and a bubble in which growth stocks were overvalued is another plausible way. I think that these authors have some more work to do before they make a convincing case that U.S. equities markets were seriously undervaluing growth companies in the 1990s.

\section{Two Industries' and Four Firms" "OC"}

The paper names about a dozen leading firms in several industries as widely cited examples. It attributes the sustained success of these firms to $\mathrm{OC}$, conceptualized as a factor of production unique to these firms within their industries. I know two of the industries from which these firms are drawn, motor vehicles and computing, well enough to use them to consider the broader issues raised by the firm-level OC approach.

In automobiles, there is cross-section variation in the effectiveness of firms in managing design, production, and distribution processes. One important innovation here is undoubtedly organizational, at least in part. I refer to the Toyoda system (sometimes called Kanban or "lean production") of manufacturing automobiles. The authors link this organizational to Toyota Motor Company's current market position. That is largely right, but to understand the broader economic issues related to that calls for adding two pieces of context.

First, half a century ago when Eiji Toyoda, Ed Deming, and (especially) Taiichi Ohno were working on this organizational improvement, Toyota Motor Company was not the automobile market leader. Back then, General Motors (GM) was the acknowledged leader in "organizational capital" in that industry, based on the (also undoubtedly organizational, at least in part) innovations of Alfred P. Sloan at GM. ${ }^{5}$ Dramatic improvements in "organizational capital" may create huge gains to society, as they did in this case-twice. General Motors created a new form of organization to leapfrog market leader Ford; Toyota in turn created a new form of organization to leapfrog GM. 
The point is the basic one of creative destruction. Society's stock of OC does not necessarily come from existing dominant firms, but instead from the dynamic incentives of entrepreneurial outsiders. Society has an interest in the organization of markets as well as of firms. Markets in which creative destruction can play out create new $\mathrm{OC}$ - by destroying the economic value of old OC.

Second, measuring the stock of OC by comparing leading firms to others is a dangerous business. Successful imitation by other automobile firms lowers Toyota's measured OC but not its actual OC. It increases the social stock of OC. To the extent that prices fall from successful imitation and competition, the imitating firms do not have any measured OC. Similarly, GM's measured OC fell as other firms (Ford, Chrysler, and the ancestors of American Motors) imitated its organization, and fell further when new competitive organizations like Toyota entered.

Again, the basic conceptual point comes from the economics of competitive markets. There is no simple and direct relationship between firm performance and industry performance. Society's stock of OC cannot be calculated by adding up the stocks of firm OC as measured in this paper.

The authors bring up two examples of firms from the computer industry where they see "organizational capital" as the source of sustained leading positions: IBM and Microsoft. This is partly right, and it raises a new issue. Both of those firms originally built leading positions in that industry through superior performance. ${ }^{6}$ IBM's superior performance clearly had organizational roots, as Tom Watson, Jr., built a firm that could both invent and market large-scale computers. Microsoft's early superior performance was more related to the brilliance of the entrepreneurs who founded it, Paul Allen and (especially) Bill Gates.

The long-term success of both of those firms has other causes, however. Each had a long run as the dominant firm in its industry (Microsoft's continues today). The idea that something you might call "organizational capital" sustained either firm in its long period of industry dominance is false. It was not superior performance that kept IBM in a position of leadership through the 1970s and 1980s, nor is it superior performance that keeps Microsoft in a position of leadership today.

Long after its organization had become a liability rather than an asset, IBM held on to market dominance in the mainframe computer industry. The advantages that sustained it were positional, not organizational. Years later, when a long, slow process finally removed IBM from its prior position, the importance of competition and ideas from outside was universally acknowledged, even from ex-IBMers. While slow, the process of creative destruction ultimately worked.

In the present, Microsoft's dominant position in the personal computer (PC) industry does not arise from superior organization. When Internet 
entrepreneurs came along, they outinvented and outmarketed Microsoft-just as the young Microsoft outperformed IBM in the early days of the PC. Microsoft continued its dominance by blocking distribution of competitively threatening technologies. ${ }^{7}$ Where the fall of IBM is an example of successful creative destruction, Microsoft's ability to evade competition is an example of blocked creative destruction.

The broad point is that "what's good for GM is good for the country" is nonsense. What's good for the continued growth of the United States and of the world economy is the competitive system that permits creative destruction. Current public policy in the United States has permitted Microsoft to evade even the threat of creative destruction from new competitors born on the Internet. Current public policy is leaning strongly toward putting the "baby bells" back in the position AT\&T once enjoyed. When public policy faces decisions like that, it is important to remember the distinction between the economy's stock of $\mathrm{OC}$, which includes dynamic competition, and leading firms' stock of measured OC, which is larger when there is less dynamic competition.

The paper by Lev and Radhakrishnan focuses on productivity growth in large, existing firms, especially ones that are relatively successful in their industry. The paper makes an argument in favor of focusing exclusively on that topic in the study of productivity growth in the whole economy. The exclusivity is a mistake; the error made by this paper in arguing for exclusivity is a form of an increasingly common error.

\section{Productivity, Economic Growth, and Organization}

Is individual firm OC the growth pole of the U.S. economy? Is sustained firm-level success caused by superior organization pervasive in the economy, observed in almost every industry? Is firm-level OC "the major source of competitive advantage" that we should be careful to value? Is the central locus of this OC in large, established, successful firms? With or without the "organization capital" label, the view that all these questions should be answered "yes" is growing more common in discussion of economic policy formation. That view makes an error at two levels.

The view omits most of the forces that matter to productivity growth at the economywide level. It leaves out fundamental advances in science and engineering, for example, and their later conversion into commercially valuable products and processes. It leaves out firm growth, birth, and death, and the importance of market selection in productivity growth. Perhaps most important, it leaves out entrepreneurship and the possibility of creative destruction.

At a second level, that view makes an important conceptual error. Around 1970, the world looked to firms like IBM, GM, and AT\&T as ex-

7. While these claims are controversial, they should not be. They are what the Microsoft documents showed and what the courts, both in trial and on appeal, have found. 
emplars of excellence in organization. Public policy listened to the idea that they were an excellent form of organization, as did business policy. Later, in the 1980s, many studies of productivity growth looked to international comparisons. The higher rate of productivity growth in Japan than in the United States led to the advice that business and public policy should emulate Japanese keiretsu. My point is that closely linking analysis at the firm level to analysis at the national or world economic growth level is a common mistake.

Indeed, the single most common usage of the phrase "new economy" that forms part of the title of this conference was "new economy company." That meant something very particular in the firm valuation theory that drove the stock market bubble of the late 1990s. It meant that firm-level organizational capital of a new form was the engine of economic growth. A particular form of startup was supposed to be the key exemplar of superior performance.

And now we are returning to the view that large-scale successful enterprises have valuable lessons for public policy and business policy - the view of this paper and much other recent analysis. Like the earlier version of that view (1970) or the view that keiretsu were the way to go (1980s) or that overcaffeinated startups had all the organizational capital (1990s), this new view is shortsighted.

The error in all four analyses is the same. The error is not the specific one that we paid "too much attention" to large established firms in the 1960s or today or that we paid "too much attention" to startups in the late 1990s or "too much attention" to Japan in the 1980s. The mistake lies in thinking that it is a sensible approach to productivity growth analysis to have a system where we "pay attention" in this sense to anything at all. The view in which scholarship has the job of figuring out what kind of firm organization is a good kind, and business and public policy have the job of "paying attention" to the scholarship and thus to the form of firm, is dangerous nonsense. It reduces economics to a kind of second-rate industrial engineering, and injects an element of central planning into policy formation.

Ignoring markets is a serious oversight, both conceptually and for measurement. While organization at the firm level is economically important, focusing too closely on success at the level of the firm ignores much of what is important for growth in a market economy. Measures of firm success that are based in comparison to other firms must take market competition into account.

\section{References}

Baily, Martin Neil, Charles Hulten, and David Campbell. 1992. Productivity dynamics in manufacturing plants. Brookings Papers on Economic Activity, Microeconomics: 187-249.

Bresnahan, Timothy, Erik Brynjolfsson, and Lorin Hitt. 2002. Information tech- 
nology, workplace organization, and the demand for skilled labor: Firm level evidence. Quarterly Journal of Economics 117 (1): 339-76.

Bresnahan, Timothy, and Franco Malerba. 1999. Industrial dynamics and the evolution of firms' and nations' competitive capabilities in the world computer industry. In Sources of industrial leadership: Studies of seven industries, ed. David C. Mowery and Richard R. Nelson, 79-132. Cambridge: Cambridge University Press.

Cockburn, Iain, and Rebecca Henderson. 1998. Absorptive capacity, coauthoring behavior, and the organization of research in drug discovery. Journal of Industrial Economics 46 (2): 157-82.

Griliches, Z., and J. Mairesse. 1998. Production functions: The search for identification. In Econometrics and economic theory in the twentieth century: The Ragnar Fisch centennial symposium, ed. Steinar Strøm, 169-203. Cambridge: Cambridge University Press.

Milgrom, Paul, and John Roberts. 1992. Economics, organization, and management. Englewood Cliffs, NJ: Prentice Hall.

Olley, Steve, and Ariel Pakes. 1996. The dynamics of productivity in the telecommunications equipment industry. Econometrica 64 (6): 1263-98.

Womack, James P., and Daniel T. Jones, and Daniel Roos. 1991. The machine that changed the world: The story of lean production. New York: Harper Collins. 